\title{
Molecular phylogenetic analyses reveal three new Ceratocystis species and provide evidence for geographic differentiation of the genus in Africa
}

\author{
Mbenoun M, Wingfield MJ, Begoude Boyogueno AD, Wingfield BD, Roux J
}

\begin{abstract}
The emergence of wattle wilt disease on non-native Acacia mearnsii trees in Africa, caused by the indigenous fungus Ceratocystis albifundus, has highlighted a need to better understand the diversity, ecology and distribution of Ceratocystis species in natural African environments. In this study we applied phylogenetic inference to identify and characterize isolates of Ceratocystis collected in a natural savanna ecosystem in South Africa. Three new species were recognized and are described as C. cryptoformis sp. nov. in the C. moniliformis complex, as well as C. thulamelensis sp. nov. and C. zambeziensis sp. nov., both residing in the $C$. fimbriata complex. Incorporating the new species into global phylogenies of Ceratocystis provided insights into the patterns of evolution and biogeography of this group of fungi. Notably, the African continent was identified as an important centre of diversification of Ceratocystis spp., from which several lineages of these fungi were shown to have radiated.
\end{abstract}

\section{Introduction}

It is well known that natural ecosystems harbor unknown pathogens and novel pathotypes threatening cultivated plant systems. These wild pathogens and their co-evolved hosts generally occur in dynamic equilibrium (Frank 1992; Thompson and Burdon 1992), maintaining low disease incidence in steady environmental conditions (Dinoor and Eshed 1984; Burgess and Wingfield, 2002). Widespread epidemics in natural plant communities involving native pathogens arise as a consequence of a disruption of this equilibrium. This may happen shortly after evolutionary changes in pathogen populations that give rise to more aggressive pathotypes, or more commonly, in association with anthropogenic disturbances or dramatic changes in environmental conditions that affect host susceptibility (Castello et al. 1995; Burdon et al. 2006; Anderson et al. 2004; Dodds and Thrall 2009). In contrast, when wild pathogens are introduced into cultivated plant systems, they are more likely to initiate devastating disease outbreaks as is the case for several fungal diseases of agricultural and forestry importance (Stukenbrock and Mcdonald 2008). 
A vivid illustration of the consequences associated with the adoption of wild plant pathogens in cultivated plant systems is found in the Wattle Wilt Disease (WWD) system affecting forest plantations based on Australian Acacia species in Africa. The WWD is caused by the fungus Ceratocystis albifundus M. J. Wingf., De Beer \& M. J. Morris (Wingfield et al. 1996). The disease was first discovered in South Africa on A. mearnsii De Wild. (Morris et al. 1993). It is now known to be distributed, at least, across southern and eastern Africa (Roux et al. 2001b, 2005; Heath et al. 2009) and may affect other non-native Acacia species (Morris et al. 1993). Interestingly, C. albifundus has been found colonizing wounds on several native African trees in natural ecosystems, in the absence of disease (Roux et al. 2007; Kamgam et al. 2008). This, in addition to supporting evidence from population genetic studies (Roux et al. 2001a; Barnes et al. 2005), has led to the view that the wattle wilt pathogen is native to Africa. The WWD is the most serious Ceratocystis disease affecting plantation forestry using A. mearnsii in Africa (Roux and Wingfield 2009), and as an emerging "new encounter disease" (Parker and Gilbert 2004), could result in terrible ecological consequences if it were to be introduced into the natural range of wattle trees in Australia (Roux and Wingfield 2013).

Ceratocystis species are ascomycete fungi residing in the order Microascales (Schoch et al. 2009; Réblová et al. 2011). Their morphological characteristics typically combine bulbous ascomatal bases with extended necks in their sexual states and deep-seated, tubular phialides in their asexual states (Nag Raj and Kendrick 1975, Upadhyay 1981). DNA sequence data and molecular phylogenetics have profoundly impacted on the taxonomy of this group of fungi, starting with the recognition of $C$. albifundus as a novel species, distinct from C. fimbriata Ellis \& Halst. (Wingfield et al. 1996). This group is now recognized, based on DNA sequence comparison, morphology and ecology, to include very distinct evolutionary lineages and species complexes for which discrete genera will be established (Wingfield et al. 2013). One of these will accommodate species in the C. fimbriata complex that includes C. albifundus and many other, mainly pathogenic species (Baker et al. 2003; Johnson et al. 2005; Van Wyk et al. 2013). However, taxonomic studies of Ceratocystis spp. are still compounded by the lack of distinctive morphological characters between closely related species and the limited resolution of molecular markers available (Van Wyk et al. 2010, 2011a, b, 2012; Kamgan Nkuekam et al. 2012a, b), limiting quick and accurate identification of these pathogens.

One of the first studies to consider the identity of Ceratocystis spp. in natural woody ecosystems in South Africa resulted in the discovery of $C$. savannae Kamgan \& Jol. Roux in the savanna dominated Kruger National Park (KNP) and C. tsitsikammensis Kamgan \& Jol. Roux in the Garden Route National Park 
(GRNP) of South Africa (Kamgan Nkuekam et al. 2008). The latter fungus showed considerable virulence when inoculated onto its native host, Rapanea melanophloeos (L.) Mez (Kamgan Nkuekam et al. 2008). In an attempt to explore the extent and determinants of the diversity of Ceratocystis spp. in the savanna ecosystem in South Africa, an extensive survey of animal-induced tree wounds was conducted throughout the KNP over 2009 and 2010. The aim of the present study was to ascertain the taxonomic and phylogenetic status of the fungi collected during this survey. This was achieved by comparing our isolates with well-known species of Ceratocystis using multi-gene DNA phylogenies, together with morphological characterization of representative isolates for novel taxa.

\section{Materials and methods}

\subsection{Collection of isolates}

Plant material for the isolation of Ceratoystis species was obtained from various native savanna trees, damaged by animals, especially elephants, in the KNP during 2009 and 2010. Collections were made in four areas inside KNP (including Letaba, Punda Maria, Satara and Skukuza), from fresh (less than onemonth-old) wounds on branches and stems of all trees showing damage. Wounds were inspected for the presence of fruiting bodies resembling species of Ceratocystis using a $10 \times$ magnification hand lens to determine the suitability of material for collection. Samples were placed into brown paper bags, one bag for each tree sampled, and transported to the laboratory for isolation. When present, nitidulid beetle associates of Ceratocystis species were collected using an aspirator and they were transported to the laboratory in glass vials.

Isolation from plant material was done by placing infected wood and bark in humid chambers to encourage the sporulation of fungal fruiting structures. Small sections $\left(\sim 1-2 \mathrm{~cm}^{2}\right)$ of plant material were also wrapped between carrot discs to bait for Ceratocystis spp. (Moller and De Vay 1968). The same method was used to isolate Ceratocystis spp. from nitidulid beetles, by crushing the insects onto carrot discs.

All isolations were incubated at $25{ }^{\circ} \mathrm{C}$ for $5-10$ days. They were regularly inspected under a dissecting microscope, and where Ceratocystis structures had developed, purification was done by lifting a few mycelial strands or single ascospore droplets using a sterile needle and transferring these to sterile $2 \%$ malt extract agar (MEA) (Biolab, Midrand, South Africa) supplemented with $\sim 0.01 \mathrm{~g} / \mathrm{L}$ streptomycin sulphate (Sigma, Steinheim, Germany). 
Purified fungal strains were obtained by sub-culturing from single hyphal tips or spore droplets and these were maintained on MEA. Fungal strains obtained from single sampled trees were sorted into morphotypes based on cultural characteristics and when possible two representatives of each morphotype were selected for molecular typing. All selected strains were eventually broadly divided into three morphogroups representing the $C$. fimbriata (including C. albifundus) complex (C. fimbriata s.1. group), the C. moniliformis (Hedgc.) C. Moreau complex (C. moniliformis s.l. group) and the Thielaviopsis thielavioides (Peyr.) A.E. Paulin, T.C. Harr. \& McNew complex (T. thielavioides s.1. group).

\subsection{DNA extraction, PCR and sequencing}

DNA extraction was based on the CTAB (cetyl trimethyl ammonium bromide) protocol developed by Möller et al. (1992). All the selected fungal strains were maintained on MEA at $25^{\circ} \mathrm{C}$ for $7-14$ days, whereafter mycelium was scraped from the surfaces of cultures, freeze-dried and ground, using a Retsch cell disrupter (Retsch Gmbh, Germany), to a fine powder that was used as starting material for total genomic DNA isolation. Final DNA working concentrations were adjusted to $\sim 75 \eta \mathrm{g} \mu \mathrm{L}^{-1}$, using a Thermo Scientific NanoDrop ${ }^{\circledR}$ ND-1000 Spectrophotometer (NanoDrop Technologies, Wilmington, DE, USA).

For first level species delineation and identification, two nuclear gene regions were selectively amplified with polymerase chain reactions (PCR) and sequenced for all selected fungal strains. These were the internally transcribed spacer (ITS) region including the 5.8S rDNA of the ribosomal RNA gene cluster for isolates representing the $C$. fimbriata s.l. and $T$. thielavioides s.l. groups, and a portion of the beta-tubulin ( $\beta$-tubulin) gene for isolates representing the $C$. moniliformis s.l. group. Additional sequences were generated for the translation elongation factor 1-alpha (TEF-1 $\alpha$ ) gene and where applicable the ITS and $\beta$ tubulin and used for in depth multigene phylogenetic analyses. These involved only a few representatives of each of the putatively distinct taxa. The oligonucleotide primer combinations utilized were respectively the ITS1 (5'-TCCGTAGGTGAACCTGCGG-3') and ITS4 (5'-TCCTCCGCTTATTGATATGC-3') for the ITS (White et al. 1990), $\beta \mathrm{t} 1 \mathrm{a}$ (5'-TTCCCCCGTCTCCACTTCTTCATG-3') and $\beta \mathrm{t} 1 \mathrm{~b}$ (5'GACGAGATCGTTCATGTTGAACTC-3') for the $\beta$-tubulin (Glass and Donaldson 1995) and EF1F (5'TGCGGTGGTATCGACAAGCGT-3') and EF2R (5'-AGCATGTTGTCGCCGTTGAAG-3') for the TEF$1 \alpha$ (Jacobs et al. 2004) gene regions.

For all gene regions, PCR reactions were performed in a $25 \mu \mathrm{L}$ final volume. Each reaction contained 2.5 $\mu \mathrm{L}$ of $10 \times$ Expand $\mathrm{HF}$ buffer with $\mathrm{MgCl}_{2}(25 \mathrm{mM}$ ) (Roche Diagnostic $\mathrm{GmbH}$, Mannheim, Germany), 2.5 $\mu \mathrm{L}$ of deoxynucleotide triphosphate $(\mathrm{dNTP}) \mathrm{mix}(10 \mathrm{mM}), 0.5 \mu \mathrm{L}$ of each primer $(10 \mathrm{mM}), 1 \mu \mathrm{L}$ of Taq 
polymerase (1 U/ $\mu \mathrm{L}$ ) (Roche Diagnostic GmbH, Mannheim, Gemany) and $1 \mu \mathrm{L}$ of DNA template. Reactions were run on a Bio-Rad iCycler thermocycler (BIO-RAD, Hercules, CA, USA). The same thermal cycling conditions were applied for the ITS and $\beta$-tubulin regions, which included an initial denaturation step at $96{ }^{\circ} \mathrm{C}$ for $2 \mathrm{~min}$ followed by 35 cycles of $30 \mathrm{~s}$ at $94{ }^{\circ} \mathrm{C}, 60 \mathrm{~s}$ at $54{ }^{\circ} \mathrm{C}$ and $90 \mathrm{~s}$ at $72{ }^{\circ} \mathrm{C}$ and a final extension step at $72{ }^{\circ} \mathrm{C}$ for $10 \mathrm{~min}$. For the TEF- $1 \alpha$, the thermal cycle comprised an initial denaturation at $96{ }^{\circ} \mathrm{C}$ for $4 \mathrm{~min}$ followed by 10 primary amplification cycles of $40 \mathrm{~s}$ at $94^{\circ} \mathrm{C}$ (denaturation), $40 \mathrm{~s}$ at $55^{\circ} \mathrm{C}$ (annealing) and $45 \mathrm{~s}$ at $72{ }^{\circ} \mathrm{C}$ (extension), then 30 additional cycles of the same reaction sequence, with a $5 \mathrm{~s}$ increase in the annealing step per cycle. Reactions were completed with a final extension step at $72{ }^{\circ} \mathrm{C}$ for $10 \mathrm{~min}$. Amplification was confirmed by staining PCR products (4 $\mu \mathrm{L}$ aliquots) with $1.5 \mu \mathrm{L}$ of $\mathrm{GelRed}^{\mathrm{TM}}$ (Biotium Incorporation, USA) nucleic acid dye and performing electrophoresis along with a DNA molecular weight marker (100 bp ladder) (Fermentas O' Gene Ruler ${ }^{\mathrm{TM}}$ ) on $2 \%$ agarose gels, followed by visualization under UV light. PCR products were purified by gel filtration using $6 \%$ Sephadex G-50 (50-150 $\mu \mathrm{m}$ bead size) (Sigma, Steinheim, Germany).

Forward and reverse sequencing reactions were performed in $12 \mu \mathrm{L}$ final volumes with the same primers as used for amplification reactions. The mixtures contained $2.5 \mu \mathrm{L}$ sequencing buffer, $0.5 \mu \mathrm{L}$ Big Dye ready reaction mixture with Amplitaq DNA polymeraze (Perkin-Emmer, Warrington, UK), $1 \mu \mathrm{L}$ of the selected primer $(10 \mathrm{mM})$ and $4 \mu \mathrm{L}$ purified PCR product. The thermal cycling conditions comprised 25 cycles of $10 \mathrm{~s}$ at $96{ }^{\circ} \mathrm{C}, 5 \mathrm{~s}$ at $50{ }^{\circ} \mathrm{C}$ and $4 \mathrm{~min}$ at $60{ }^{\circ} \mathrm{C}$. Sequencing products were purified through Sephadex G-50 gel columns and concentrated in an Eppendorf 5301 vacuum concentrator, at $45{ }^{\circ} \mathrm{C}$. They were thereafter run on an ABI PRISM ${ }^{\mathrm{TM}} 3100$ DNA Analyzer (Applied BioSystems, 142 Foster City, California). Some fungal strains in the C. fimbriata group, including those representing C. albifundus, necessitated the cloning of amplified PCR products for the ITS prior to sequencing. This was done using the $\mathrm{pGM}^{\circledR}$-T Easy Vector System (Promega Corporation, Madison, USA) following the manufacturer's instructions.

\subsection{Species delineation and primary identification}

Consensus sequences were assembled from forward and reverse sequencing reads using MEGA version 5 (Tamura et al. 2011). Multiple sequence alignments were constructed using MAFFT (http://www.align.bmr.kyushu-u.ac.jp/mafft/online/server/) version 6 (Katoh et al. 2005) and edited manually in MEGA. The ITS sequence dataset was used for species delineation in the C. fimbriata s.l. and T. thielavioides s.1. groups, while the $\beta$-tubulin dataset was used for the $C$. moniliformis s.1. group. For this purpose, we applied the General Mixed Yule Coalescent (GMYC) model statistical approach developed by Pons et al. (2006). The GMYC model uses branching patterns in an ultrametric phylogenetic tree to 
delineate species, by identifying the point of transition between micro- and macro-evolutionary processes when diversification rates are plotted against evolutionary times. This is followed by a log likelihood ratio (LR) test to assess the goodness-of-fit of the GMYC model as compared to a null model that assumes a single population under neutral coalescence.

We implemented the GMYC model using the SPLITS (http://r-forge.r-project.org/projects/splits/) package (Ezard et al. 2009) of the statistical software R (R development Core Team 2011). Ultrametric trees were constructed through Bayesian Markov Chain Monte Carlo (MCMC) algorithms as implemented in BEAST v1.5.4. (Drummond and Rambaut 2007), under a strict molecular clock, constant population size and coalescent prior settings. Prior to this, duplicate sequences were excluded from the alignments for the C. moniliformis group, using the 'unique.seqs' command of MOTHUR v.1.21.1 (Schloss et al. 2009) and best-fit models of nucleotide substitution were estimated using JModel Test version 2.2 (Posada 2008). For each sequence alignment, two parallel MCMC runs were set for $10^{7}$ generations, starting from a UPGM tree. Trees were selected every 1000 generations. Convergence of the two chains was checked using Tracer v 1.5 (Rambaut and Drummond 2009). The resulting tree files were combined using Logcombiner (included in the Beast package), discarding the first $10 \%$ of the generations from each run as burn-in. Maximum credibility trees were generated in TreeAnnotator (also included in the Beast package) enforcing the $5 \%$ posterior probability limit.

Representative sequences of each GMYC independent entity were evaluated against published authenticated sequences from GenBank, using NCBI-Blast (http://www.ncbi.nlm.nih.gov/Blast.cgi), for possible matching with sequences of known species. From this primary identification process, 24 isolates form KNP (Table 1), including two or three representative isolates for each known species and four for putative knew species, were selected for in depth, multigene phylogenetic analyses.

\subsection{Multi-gene phylogenetic analyses}

Parallel analyses were conducted for the three Ceratocystis species complexes represented in our collection, namely C. fimbiata s.1., C. moniliformis s.l. and T. thielavioides s.1. For each of these groups, three sequence datasets representing each of the ITS, $\beta$-tubulin and TEF- $1 \alpha$ gene regions were constructed. These datasets included sequences generated in this study as well as reference sequences sourced from GenBank for two representative strains of all known species in the respective complexes (Table 1). The $C$. fimbriata s.l. and T. thielavioides s.l. group datasets were supplemented with reference sequences for $C$. virescens (R.W. Davidson) C. Moreau, which was chosen as the outgroup taxon in 
phylogenetic reconstructions. C. moniliformopsis Yuan \& Mohammed was used as the outgroup taxon for the C. moniliformis s.l. group.

Sequences were aligned as previously described using MAFFT. A first round of analyses involving whole datasets included maximum parsimony (MP) and Bayesian inferences of phylogeny applied to concatenated, multi-locus sequence data of the three gene regions. In a second tier of analyses, only the apparently new species in the $C$. fimbriata s.1. and $C$. moniliformis s.l. groups and their closest relatives were considered. The phylogenetic relationship of these taxa based on single locus data of the ITS, $\beta$ tubulin and TEF-1 $\alpha$ genes was investigated using MP analyses.

Maximum Parsimony analyses were performed using PAUP version 4.0b10* (Swofford 2002). Uninformative characters were excluded and all informative characters were unordered and of equal weight. For the C. fimbriata s.l. group, two gap treatments were considered, first as "new character" state and then as "missing data", while for the C. moniliformis s.1. and T. thielavioides s.1. groups only the "new character state" was applied. MP trees were generated via a heuristic tree search involving 100 random stepwise addition replicates and tree-bisection-reconstruction (TBR) branch-swapping. Statistical support for branch nodes of most parsimonious trees (MPTs) was assessed using 1000 bootstrap replicates. Other parameters estimated for MPTs included the tree length (TL), consistency index (CI), retention index (RI) and rescaled consistency indexes (RC). The PAUP settings, as well as tree parameters estimated for single locus analyses, were the same as those implemented in combined multi-gene analyses. Furthermore, the genealogical concordance of the three genes was tested using partition homogeneity tests (PHT) with 1000 heuristic search replicates in PAUP (Swofford 2002).

Bayesian phylogenies were inferred based on Markov Chain Monte Carlo (MCMC) analyses with MrBayes v3.1.2 (Ronquist and Huelsenbeck 2003). Best-fit models of nucleotide substitutions were selected using JModeltest version 2.2 (Posada 2008) under the Akaike information criterion (AIC). All the models selected were of the standard General-Time-Reversible (GTR) type with gamma-distribution of substitution rates. The MCMC procedure involved four chains and started from a random tree topology. Sampling every $100^{\text {th }}$ generation, one million random tree generations were performed for each of the $C$. moniliformis s. 1. and T. thielavioides s.l. datasets, whereas for the C. fimbriata s.l. dataset 5 million generations were necessary to reach a stationary phase in the distribution of sample likelihoods. Posterior probability distributions were assessed with Tracer v1.5 (Rambaut and Drummond 2009), and the default burn-in setting of the first $10 \%$ of the generations was enforced in the construction of maximum credibility consensus trees. Final consensus trees were visualized using FigTree (Morariu et al. 2008). 


\subsection{Culture characteristics and morphology}

Two isolates representing each of the purported new Ceratocystis species emerging from the phylogenetic analyses were selected for culture and morphological studies. These isolates were maintained on $2 \%$ MEA at room temperature. Optimum growth temperatures were determined by comparing colony diameters at six different temperatures, ranging from 10 to $35^{\circ} \mathrm{C}$ at $5{ }^{\circ} \mathrm{C}$ intervals. For each isolate and at each temperature five replicate plates were prepared by transferring 8-mm-diameter agar plugs from the margins of actively growing cultures to the centers of Petri dishes (90mm) containing fresh, sterile $2 \%$ MEA. Plates were incubated in the dark for 3 or 14 days depending on whether they were related to $C$. moniliformis s.l. or C. fimbriata s.l. Colony diameters were measured along two perpendicular axes centred on the plugs, and averages and standard deviations were computed.

Morphological characteristics were determined using 2-wk and 3-wk-old cultures maintained at their optimum growth temperature, respectively for the C. moniliformis s.l. and C. fimbriata s.1. groups. The mycological colour charts of Rayner (1970) were used to record colony colours. Fungal structures were mounted on microscope slides in $85 \%$ lactic acid and examined under a Zeiss Axioskop microscope (Carl Zeiss Ltd, Germany). Images of structures were captured with a HRc Axiocam digital camera fitted to the microscope and structure sizes were determined with the Axiovision 3.1 software also fitted to the microscope. Where possible, 50 measurements were taken for each taxonomically informative morphological character for isolates chosen to represent holotypes, and 10 measurements for isolates chosen as paratypes of new taxa. Specific means and standard deviation values were computed for each character. These measurements are presented as the extremes in brackets and the range represented by the mean over all holotype and paratype measurements, plus or minus the standard deviations.

All isolates designated as holotypes and paratypes in morphological descriptions are maintained in the culture collection (CMW) of the Forestry and Agricultural Biotechnology Institute (FABI), University of Pretoria, South Africa. The same isolates have also been deposited with the Centraalbureau voor Schimmelcultures (CBS), the Netherlands and dried herbarium specimens were deposited in the National Collection of Fungi (PREM), Pretoria, South Africa. 


\section{Results}

\subsection{Isolates}

A total of 308 fungal isolates representing three species lineages in the broadly defined Ceratocystis s.l. (Wingfield et al. 2013) were collected in this study. Based on morphology, these included 186 isolates resembling species in the $C$. moniliformis complex, 114 isolates resembling those in the $C$. fimbriata complex (including 104 isolates of $C$. albifundus) and eight isolates resembling species in the $T$. thielavioides complex. A representative selection of this collection of isolates has been preserved in the culture collection (CMW) at FABI.

Ceratocystis spp. were isolated from various native savanna trees, representing 25 species, 17 genera and 10 plant families (Table 2). They occurred in association with at least six species of nitidulid beetles that belonged to the genera Brachypeplus (B. ater Grouvelle) and Carpophilus (including Ca. apicipennis Fairmaire, Ca. bisignatus Boheman, Ca. dimidiatus (Fabricius), Ca. hemipterus L. and one unidentified species.

\subsection{Species delineation}

\subsubsection{Ceratocystis moniliformis s.l. group}

Successful amplification and sequencing of the $\beta$-tubulin gene region was achieved for all selected isolates in the $C$. moniliformis s.1. group, producing sequences of a relatively constant length of about $497 \mathrm{bp}$. The $\beta$-tubulin dataset comprised 69 unique haplotypes and the best-fit model of nucleotide substitution selected for this dataset was TIM1 ef $+\mathrm{G}$. The GMYC analysis applied to the $\beta$-tubulin gene produced a model with three independent groups (Figure 1). The model was supported by a significant LR test (likelihood of null model: 589.7; maximum likelihood of GMYC model: 594.6143; LR test: 0 $\left..02111723^{*}\right)$. Two of these groups were respectively identified using NCBI-BLAST as C. oblonga R.N. Heath \& Jol. Roux and C. savannae, showing 99-100\% homology with GenBank accessions of respective species. The third group was closely related to, but different, from both $C$. oblonga and $C$. savannae. This group was considered to represent an undescribed species.

\subsubsection{Ceratocystis fimbriata s.l. and T. thielaviopsis s.l. groups}

ITS sequences were generated for all isolates in the $T$. thielaviopsis s.l. group. Likewise, we were successful in generating ITS sequences for all isolates in the C. fimbriata s.l. group, other than $C$. albifundus. The latter could be distinguished by its unique morphological characteristics, and therefore 
only three isolates of this species were sequenced to supplement the ITS sequence dataset. Isolates involved in vector-cloning produced multiple polymorphic ITS copies. However, differences between sister sequences were phylogenetically insignificant, and we used the 'consensus.seqs' command in MOTHUR v.1.21.1 (Schloss et al. 2009) to create a consensus ITS sequence for each of these isolates. The ITS sequence dataset comprised 31 taxa and was heterogeneous with regards to sequence length. Two groups (509 bp and $517 \mathrm{bp}$ ) associated with Th. thielavioides s.l. and three groups ( $600 \mathrm{bp}, \sim 706 \mathrm{bp}$ and $\sim 740 \mathrm{bp}$ ) associated with $C$. fimbriata s.l. group could clearly be distinguished. The TPM2uf $+\mathrm{G}$ was selected as the best-fit model of nucleotide substitution.

The GMYC analysis was consistent with the ITS sequence length polymorphisms, delineating five independent entities (Figure 2). The model was supported by a highly significant LR value (likelihood of null model: 132.0526; maximum likelihood of GMYC model: 137.8351; likelihood ratio: 11.56507; LR test: $\left.0.00903173^{* *}\right)$. The GenBank BLAST-search identified the two Thielaviopsis-related groups as Th. thielavioides and Th. basicola (Berk. \& Broome) Ferraris and confirmed the identity of C. albifundus with maximum similarity index. The remaining two groups of isolates related to the $C$. fimbriata complex did not match any known species from the GenBank database. They were considered to represent two new species.

\subsection{Multi-gene phylogenetic analyses}

\subsubsection{Ceratocystis moniliformis s.l. group}

The concatenated data matrix for isolates in the C. moniliformis s.l. group included 36 taxa and 1141 total characters to which the ITS, $\beta$-tubulin and TEF-1 $\alpha$ gene partitions contributed 374, 442 and 325 characters respectively. The total number of parsimony-informative characters was 193, whereas the number of parsimony-uninformative characters was 948, which included 14 variable parsimony-uninformative and 934 constant characters. The heuristic search resulted in nine equally MPTs of 288 steps $(\mathrm{CI}=0.83, \mathrm{RI}=$ $0.95, \mathrm{RC}=0.79$ ), (Figure 3 ). The four isolates representing the putative new species from KNP formed a strongly supported (97\% bootstrap) clade, whereas the remaining KNP isolates grouped with the reference strains for C. oblonga and $C$. savannae in two less well-resolved sister groups. The Bayesian phylogenetic reconstruction supported the MP tree topology, producing $100 \%$ posterior probability for the clade representing the putative new species. 
In the MP analyses based on single genes, only the $\beta$-tubulin gene sequence data could resolve the isolates representing the new species with strong (99\%) bootstrap support (Figure 4). This apparently undescribed species was monophyletic with the TEF-1 $\alpha$ gene but showed incomplete lineage sorting with C. oblonga. The PHT $(p$-value $=0.001)$ indicated little phylogenetic congruence between the three genes. This reflected the poor resolution of the ITS and TEF-1 $\alpha$ gene sequences, rather than any major conflict between single MP tree topologies.

\subsubsection{Ceratocystis fimbriata s.l. group}

The concatenated data matrix for isolates in the C. fimbriata s.l. group comprised 69 taxa and 1908 total characters, including 654 characters from the ITS gene, 559 characters from the $\beta$-tubulin gene and 695 characters from the TEF-1 $\alpha$ gene. When gaps were considered as new character states, 1001 characters were constant, 230 variable and parsimony-uninformative and 667 were variable but parsimonyinformative. Treating gaps as missing data changed these values to 1250, 162 and 496 respectively. Seven equally most MPTs of 1818 steps were obtained from the heuristic search when the first gap treatment was enforced, whereas with the second gap treatment, 100 MPTs of 1146 steps were obtained. In both cases the same values for goodness of character fit indices $(\mathrm{CI}=0.62, \mathrm{RI}=0.87, \mathrm{RC}=0.54)$ were obtained. Isolates representing the two putative new species from KNP were consistently resolved in two distinct clusters with $100 \%$ bootstrap support. Likewise, two isolates initially identified as C. albifundus clustered with reference strains of this species, also with $100 \%$ bootstrap, but formed a distinctive sub-clade $(>80$ $\%$ bootstrap).

Tree topologies under the two gap treatments displayed some differences, especially regarding the placement of the KNP taxa and their relationship with C. larium M. Van Wyk \& M.J. Wingf. With a full consideration of gaps in the analyses, these fungi shared a relatively recent common ancestor, one of the new species forming a strong (100\% bootstrap) group with C. tsitsikammensis, whereas the other grouped loosely with C. larium, C. albifundus and C. tangayicensis R.N. Heath \& Jol Roux. When considering gaps as missing data, a different arrangement of relatedness was derived, in which only the strong association between $C$. tsitsikammensis and one new species was retained. C. larium emerged as more closely related to the clade comprising C. atrox M. van Wyk \& M.J. Wingf. and C. pirilliformis I. Barnes \& M.J. Wingf. than to C. albifundus, as it has previously been presented (Van Wyk et al. 2010, 2011a, b, 2012). This second scheme depicted a more biogeographically meaningful representation of the $C$. fimbriata lineage, circumscribing two biogeographic groups respectively centred in Africa and the Indopacific region, in addition to the well-known South and North American clades (Figure 5). Furthermore, this representation was also supported by the results from Bayesian phylogenetic inferences (Figure 5). 
Single-gene MP trees (Figure 6) each completely resolved the African biogeographic group into five distinct clusters representing the same clades as circumscribed in combined multilocus analyses. The clades representing the two putative new taxa from KNP were supported by bootstrap values ranging between $84 \%$ and $100 \%$. The $\beta$-tubulin and TEF-1 $\alpha$ trees also separated the reference strains from KNP isolates of $C$. albifundus, with strong (88-99 \%) bootstrap support. The PHT ( $p$-value $=0.5$ ) indicated high genealogical concordance between the three genes.

\subsubsection{Thielaviopsis thielavioides s.l. group}

The concatenated data matrix for isolates in the T. thielaviodes s.l. group comprised 14 taxa and 1675 characters, including 404 characters from the ITS gene, 539 characters from the $\beta$-tubulin gene and 731 characters from the TEF-1 $\alpha$ gene. The total number of parsimony-informative characters was 343 whereas the number of parsimony-uninformative characters was 1332, of which 218 were variable-parsimonyuninformative and 1114 were constant. The heuristic search resulted in one most parsimonious tree (Figure 3) of 633 steps $(\mathrm{CI}=0.85, \mathrm{RI}=0.93, \mathrm{RC}=0.79)$. The six isolates from $\mathrm{KNP}$ were distributed between two clades respectively related to Th. basicola and Th. thielavioides, with maximum bootstrap support. However, within each of these clades, the KNP isolates formed well resolved clusters. The Bayesian tree topology and posterior probabilities mirrored the MP phylogeny (Figure 7).

All alignments and phylogenetic trees generated in this study have been uploaded to TreeBase (http://purl.org/phylo/treebase/phylows/study/TB2:S14151).

\subsection{Taxonomy}

Results emerging from phylogenetic analyses of the ITS, $\beta$-tubulin and TEF- $1 \alpha$ gene sequences showed clearly that isolates of Ceratocystis from KNP represented several distinct taxa, including three new species for which morphological descriptions are provided as follows:

Ceratocystis cryptoformis M. Mbenoun \& Jol. Roux sp. nov., Figure 8, MB 804009

Etymology: this name reflects the lack of distinctive morphological characters for this species as compared to its closest relatives. 
Culture characteristics - Colonies on MEA initially hyaline to white, darkening to isabella colour (19''i), reverse grayish sepia (17,','i), after 10 d. Mycelium fluffy and superficial. Hyphae smooth or granular, septate, without constrictions at septa. Optimal temperature for growth $30{ }^{\circ} \mathrm{C}$, growth at $35{ }^{\circ} \mathrm{C}$ but no growth at $10{ }^{\circ} \mathrm{C}$. Fast growing, reaching $60-75 \mathrm{~mm}$ in diameter within $3 \mathrm{~d}$.

Sexual state - Ascomata with bulbous bases and long necks formed superficially on substrate or suspended in aerial mycelium, with a random distribution. Ascomatal bases dark brown, globose to obpyriform, often ornamented with scattered conical spines, (124-)204-348(-502) $\mu \mathrm{m}$ high and (138)185-311(-475) $\mu \mathrm{m}$ wide in diameter. Ascomatal necks dark brown, erect or slightly curled, forming disciform structures at the junction with basal bulbs, (322-)480-902(-1160) $\mu \mathrm{m}$ long, (12-)15-21(-25) $\mu \mathrm{m}$ wide at apices and (26-)39-63(-84) $\mu \mathrm{m}$ wide at bases. Ostiolar hyphae hyaline, divergent, (21-)2743(-56) $\mu \mathrm{m}$ long. Asci not observed. Ascospores accumulating in creamy to yellow droplets at the tips of ascomatal necks, surrounded by sheaths, aseptate, cucullate (hat-shaped) in side view, (5-)6-7 $\mu \mathrm{m}$ wide and 3-4 $\mu \mathrm{m}$ long.

Asexual state - typical of Thielaviopsis with enteroblastic conidium ontogeny. Conidiophores occurring solitary or aggregated in small bundles and arising laterally from vegetative hyphae, hyaline, phialidic, lageniform, (17-)20-34(-44) $\mu \mathrm{m}$ long, 2-3 $\mu \mathrm{m}$ wide at apices and (3-)4-5 $\mu \mathrm{m}$ wide at bases. Primary conidia hyaline, aseptate, cylindrical, (3-)5-6(-8) $\mu \mathrm{m}$ long and 2-3 $\mu \mathrm{m}$ wide. Secondary conidia hyaline, aseptate, diversiform, 6-9(-12) $\mu \mathrm{m}$ long and (2-)3-4(-6) $\mu \mathrm{m}$ wide. Aleurioconidia not observed.

Specimens examined: South Africa, Kruger National Park, near Skukuza (S25 07.283 E31 21.296), isolated from wound on Ziziphus mucronata, June 2010, M. Mbenoun \& J. Roux, HOLOTYPE PREM 60824, culture ex-type CMW 36828 = CBS 131279. Additional specimens: South Africa, Kruger National Park, near Skukuza (S25 03.260 E31 34.419), isolated from wound on Terminalia sericea, June 2010, M. Mbenoun \& J. Roux, PREM 60822 (PARATYPE), culture ex-type CMW 36826 = CBS 131277; KNP, near Skukuza (S25 06.009 E31 27.742), isolated from wound on Combretum zeyheri, June 2010, M. Mbenoun \& J. Roux, PREM 60823, culture ex-type CMW 36827= CBS 131278.

Ceratocystis thulamelensis M. Mbenoun \& Jol. Roux sp. nov., Figure 9, MB 804010

Etymology: the name refers to the extinct civilization of THULAMELA whose vestiges are found in the same area where this fungus was first collected. 
Culture characteristics - Colonies on MEA grayish olivaceous (21\%,'), reverse grayish olivaceous, turning dark olive-brown with age. Mycelium sparse, immersed and superficial. Hyphae smooth, septate, without constriction at septa. Optimal temperature for growth $25{ }^{\circ} \mathrm{C}$, slow-growing, $30-50 \mathrm{~mm}$ colony diameter in $2 \mathrm{wk}$, no growth at $10^{\circ} \mathrm{C}$ and at $35^{\circ} \mathrm{C}$.

Sexual state - Ascomata with bulbous bases and long necks formed superficially or partially submerged in substrate, with a scattered distribution. Ascomatal bases dark brown to black, globose, (88-)129-219(246) $\mu \mathrm{m}$ long and (70-)129-219(-243) $\mu \mathrm{m}$ wide in diameter. Ascomatal necks brown, erect, slender (203)265-407(-487) $\mu \mathrm{m}$ long, (11-)15-25(-30) $\mu \mathrm{m}$ wide at apices and (23-)28-44(-58) $\mu \mathrm{m}$ wide at bases. Ostiolar hyphae hyaline, divergent, (21-)28-48(-57) $\mu \mathrm{m}$ long. Asci not observed. Ascospores accumulating in creamy to yellow droplets at the tips of ascomatal necks, embedded in sheaths, aseptate, cucullate (hat-shaped) in side view, (5-)6-7(-8) $\mu \mathrm{m}$ wide, (2-)3-4 $\mu \mathrm{m}$ high.

Asexual state - Typical of Thielaviopsis with enteroblastic conidium ontogeny. Conidiophores of two types, phialidic, occurring solitary. Primary conidiophores hyaline at apices, turning brown towards bases with one to three basal septa when arising laterally from vegetative hyphae, lageniform, (36-)61-121(175) $\mu \mathrm{m}$ long, (2-)3-5 $\mu \mathrm{m}$ wide at apices and (2-)5-6 wide at bases, hyaline, tubular and variable in size when terminal on hyphae. Secondary conidiophores borne near the bases of ascomata, light brown, flaring, size not determined (because of scarce numbers). Primary conidia hyaline, aseptate, cylindrical or rectangular, (9-)11-17(-22) $\mu \mathrm{m}$ long and (2-)3-4 $\mu \mathrm{m}$ wide. Secondary conidia hyaline, aseptate, barelshaped, 7-10(-11) $\mu \mathrm{m}$ long and 6-8 $\mu \mathrm{m}$ wide. Aleurioconidia brown, thick-walled, globose to subglobose, (11-)13-15(-17) $\mu \mathrm{m}$ long and (10-)11-13(-14) $\mu \mathrm{m}$ wide.

Specimens examined: South Africa, Kruger National Park, near Punda Maria (S22 40.537 E31 06.893), isolated from wound on Colophospermum mopane, June 2010, M. Mbenoun \& J. Roux, HOLOTYPE PREM 60828, culture ex-type CMW 35972 = CBS 131284. Additional specimens: South Africa, Kruger National Park, near Punda Maria (S22 44.022 E31 00.956), isolated from wound on Combretum zeyheri, June 2010, M. Mbenoun \& J. Roux, PREM 60827 (PARATYPE), culture ex-type CMW 35971 = CBS 131283; South Africa, Kruger National Park, near Punda Maria (S22 40.537 E31 06.893), isolated from wound on Colophospermum mopane, June 2010, M. Mbenoun \& J. Roux, CMW 35973 = CBS 131285.

Ceratocystis zambeziensis M. Mbenoun \& Jol. Roux sp. nov., Figure 10, MB 804011 
Etymology: the name refers to the broad Zambezian ecoregion that includes the Kruger National Park and the areas where this species was collected.

Culture characteristics - Colonies on MEA greenish olivaceous (23','), reverse greenish olivaceous. Mycelium immersed and superficial. Hyphae smooth, septate, without constriction at septa. Optimal temperature for growth $25^{\circ} \mathrm{C}$, slow-growing, colony diameters reaching $\sim 60 \mathrm{~mm}$ in diameter within 2 wk, no growth at $10{ }^{\circ} \mathrm{C}$ and $35^{\circ} \mathrm{C}$.

Sexual state - Ascomata with bulbous bases and long necks formed superficially or partially submerged in substrate, with a scattered distribution. Ascomatal bases dark brown to black, globose, (100-)151229(-294) $\mu \mathrm{m}$ high and (103-)147-215(-251) $\mu \mathrm{m}$ wide in diameter. Ascomatal necks dark brown, erect, slender, (124-)288-486(-601) $\mu \mathrm{m}$ long, (11-)16-24(-44) $\mu \mathrm{m}$ wide at apices and (20-)22-34(-50) $\mu \mathrm{m}$ wide at bases. Ostiolar hyphae hyaline, convergent, (35-)43-63(-77) $\mu \mathrm{m}$ long. Asci not observed. Ascospores accumulating in creamy to yellow droplets at the tips of ascomatal necks, embedded in sheaths, aseptate, cucullate (hat-shaped) in side view, (5-)6-7(-8) $\mu \mathrm{m}$ wide, $3-4 \mu \mathrm{m}$ long.

Asexual state - Typical of Thielaviopsis with enteroblastic conidium ontogeny. Primary conidiophores hyaline at apices, turning brown towards bases, multi-septate, phialidic, tubular, tapering at apices (47)87-223(-236) $\mu \mathrm{m}$ long, (3-)4(-5) $\mu \mathrm{m}$ wide at apices and (4-)5-7 $\mu \mathrm{m}$ wide at bases. Secondary conidiophores not observed. Primary conidia hyaline, aseptate, bacilliform-shaped, (8.8-)12-18(-22) $\mu \mathrm{m}$ long and 3-4(-6) $\mu \mathrm{m}$ wide. Secondary conidia not observed. Aleurioconidia brown, thick-walled, globose to spherical, (10-)12-14(-16) $\mu \mathrm{m}$ long and (9-)12-14(-15) $\mu \mathrm{m}$ wide.

Specimens examined: South Africa, Kruger National Park, near Satara (S24 21.948 E31 45.861), isolated from wound on Combretum imberbe, June 2010, M. Mbenoun \& J. Roux, HOLOTYPE PREM 60825, culture ex-type CMW 35958 = CBS 131280. Additional specimens: South Africa, Kruger National Park, near Satara (S24 22.026 E31 45.897), isolated from wound on Acacia nigrescens, June 2010, M. Mbenoun \& J. Roux, PREM 60826 (PARATYPE), culture ex-type CMW 35963 = CBS 131282; South Africa, Kruger National Park, near Satara (S24 25.737 E31 47.265), isolated from wound on Schotia brachypetala, June 2010, M. Mbenoun \& J. Roux, culture ex-type CMW 3596 = CBS 131281. 


\section{Discussion}

This study encompasses the description of three previously unknown species of Ceratocystis namely, $C$. cryptoformis, C. thulamelensis and C. zambeziensis. These fungi were discovered during a survey of Ceratocystis spp. infecting trees in a natural savanna ecosystem in South Africa. Their primary identification among other co-occurring sister species was based on single gene sequence data, applying a statistical phylogenetic approach based on the general mixed Yule coalescent (GMYC) model (Pons et al. 2006). Multi-gene phylogenetic analyses of three gene regions, and especially the genealogical concordance phylogenetic species recognition (GCPSR) concept (Taylor et al. 2000), supported the GMYC-based identification. This highlighted the reliability of the latter method for fungal species recognition. However, the GMYC model is only as good as the taxonomic resolution of the gene region used. In this study, our selection of the ITS and $\beta$-tubulin was informed by previous studies (Van Wyk et al. 2011a, b; Kamgan Nkuekam et al. 2012a, b) that have shown that these two genes are among the best available for delineating species respectively in the $C$. fimbriata (as well as $T$. thielavioides) and $C$. moniliformis complexes.

Ceratocystis cryptoformis resides in the C. moniliformis complex (Van Wyk et al. 2006; Wingfield et al. 2013). The closest relatives of this species in the global multi-gene phylogeny of this lineage are $C$. oblonga and C. savannae, also occurring in KNP. The three species form a well-resolved group in what appears to represent an African clade of $C$. moniliformis s.l., in distinction to the Asian and Indo-pacific clades. This clade also includes T. ceramica R.N. Heath \& Jol. Roux (Heath et al. 2009), C. decipiens Kamgan-Nkuek. \& Jol. Roux and C. salinaria Kamgan-Nkuek. \& Jol. Roux (Kamgan Nkuekam et al. $2012 b)$. In the description of the latter two species, it emerged that among the three commonly used loci for inferring phylogenetic relationships in Ceratocystis, the $\beta$-tubulin gene performs the best for delineating cryptic species within the African clade of $C$. moniliformis s.l. The TEF-1 $\alpha$ showed incomplete lineage sorting, whereas the ITS showed no resolution. The results obtained from our singlelocus analyses are consistent with these observations. More generally, phylogenetic studies in Ceratocystis have been faced with the problem of limited resolution of available markers. Although in most recent cases the rule has been to follow the GCPSR, the recognition of several species has, in reality, relied on a single gene (Van Wyk et al. 2011a, b, 2012; Kamgan Nkuekam et al. 2012b). In this process, additional arguments demonstrating the robustness of such a "pseudo" GCPSR approach have been sought through haplotype networks and/or fixed nucleotide polymorphism analyses. In the present case we adopted the view that such supplementary analyses would be superfluous, considering that the taxonomic 
distinctiveness of C. cryptoformis with respect to its two closest relatives has been demonstrated using less subjective GMYC analyses based on the $\beta$-tubulin gene sequences.

Ceratocystis cryptoformis, C. oblonga and C. savannae can be considered cryptic species. They portray the same general morphological and culture characteristics typical of $C$. moniliformis s.l., including a rapid growth on artificial media, the presence of conical ornamentations on their ascocarp bases and the seeming absence of aleurioconidia (chlamydospores). C. cryptoformis may be distinguished by slightly larger ascomata or smaller primary conidia, but more generally the three species have overlapping morphometric values for taxonomically informative characters. The presence of granular hyphae in its mycelium makes $C$. cryptoformis closer to C. oblonga, whereas its temperature optimum of $30^{\circ} \mathrm{C}$ and the ability to survive at $35{ }^{\circ} \mathrm{C}$ are reminiscent of $C$. savannae. These three fungi coexist as saprophytes on tree wounds in the northern Limpopo Province of South Africa. Their growth patterns in response to various temperatures in combination with previous collection records (Kamgan Nkuekam et al. 2008, 2012b; Heath et al. 2009) suggest that the geographic distribution of C. cryptoformis and C. savannae extends northwards while that of $C$. oblonga extends southwards.

Like its two siblings, C. cryptoformis is not known outside of Africa. It is likely that the three fungi are native to Africa and the savanna ecosystem represents their natural habitat. However, while C. oblonga and C. savannae have invaded adjacent commercial plantations of non-native Acacia and/or Eucalypt tree species (Heath et al. 2009; Kamgan Nkuekam et al. 2012b), C. cryptoformis has not been detected beyond the natural savanna environment in KNP.

Ceratocystis thulamelensis and C. zambeziensis are both members of the $C$. fimbriata complex (Jonhson et al. 2005; Wingfield et al. 2013). This group was the first in Ceratocystis in which geographical differentiation was showed in its phylogenetic structure, notably with the identification of three geographic clades respectively centred in North America, South America and Asia (Johnson et al. 2005). As additional species are discovered and included in phylogenetic analyses, emerging evidence suggests that additional centres of diversification for C. fimbriata s.l. may be found elsewhere in the world. In Africa in particular, the supplementary information emerging from the two new species described here reveals that at least three clades have radiated on the continent. C. zambeziensis resides in one of these clades, along with C. tsitsikammensis and C. tanganyicensis, while C. thulamelensis and C. albifundus each represent a distinct clade with no known close relatives. All these groups have a common ancestor, which is also shared by members in the South American clade, making the circumscription of a coalesced, unique African lineage for C. fimbriata s.l. problematic. On the other hand, genetic distances between the 
African clades are considerable; for instance, C. thulamelensis is closer to the South American clade than it is to either of the two other African clades. For all these reasons, we consider it appropriate to use the terminology "African biogeographic group" to refer to C. fimbriata s.l. from Africa. A similar group can be defined for the Indo-pacific region. Our results suggest that these two biogeographic groups, as well as the South American clade, have evolved from a common ancestor.

In contrast to $C$. moniliformis s.l. species from Africa, members of the African biogeographic group of $C$. fimbriata s.l. are phylogenetically well-resolved. This is distinctly reflected in each of the three genes used in this study. Moreover, the congruence of the three genes is supported by a highly significant PHT. However, with the exception of $C$. albifundus, easily distinguishable by its unique morphology, only minor morphological differences separate species of $C$. fimbriata s.l. from Africa. These fungi portray the general characteristics inherent to the $C$. fimbriata complex, including a slow growth, the absence of ornamentation on their ascocarp bases and the production of aleurioconidia. Their morphometric characteristics for taxonomically informative characters, however, generally overlap.

Ceratocystis thulamelensis and $C$. zambeziensis have the same temperature optima at $25{ }^{\circ} \mathrm{C}$, similar to $C$. tsitsikammensis, but in contrast to C. tanganyicensis $\left(20^{\circ} \mathrm{C}\right)$ and C. albifundus $\left(30^{\circ} \mathrm{C}\right)$. The only marked differences between the two new species in their colony characteristics are the colour and rate of growth. C. thulamelensis grows more slowly, forming darker olivaceous colonies with sparse mycelium. This fungus is also characterized by its propensity to lose the capacity to form ascomata on artificial medium, usually after the first transfer. But, colony characteristics for $C$. zambeziensis are similar to those reported for C. tsitsikammensis, with which it shares a lack of, or scarcity of secondary conidia.

The three new Ceratocystis species described in this study were collected in KNP along with five previously well-known species, including C. oblonga and C. savannae in the C.moniliformis s.1. lineage, C. albifundus in the C. fimbriata s.1. lineage and T. basicola and T. thielalavioides in the T. thielavioides s.l. lineage. While it is undoubted that KNP isolates of C. savannae and C. oblonga and their respective references from GenBank are monophyletic and represent single taxonomic entities, results of this study include some evidence suggesting that populations of C. albifundus, T. basicola and T. thielavioides from the KNP may represent, or include cryptic species. This is because there was substantial polymorphism within the clades representing these species in multi-gene phylogenies. Moreover, in the case of $C$. albifundus, single-locus MP analyses based on $\beta$-tubulin and TEF- $1 \alpha$ gene sequences concordantly separated the KNP isolates from GenBank references for this species. Further investigations will be needed to clarify the taxonomic status of these isolates. 
This study highlights the fact that the diversity of Ceratocystis species in natural ecosystems in Africa is still largely overlooked. Vast areas of natural vegetation, with similar or different ecologies, exist on the continent and have not been explored. Surveying more of these natural ecosystems will result in the discovery of more species and lineages and provide important information about the distribution and host range of these fungi, especially for the taxa with the potential to initiate disease outbreaks. These studies will also provide opportunities to investigate more evolutionary questions such as those related to ecological specialization. On the other hand, we showed that careful selection of molecular markers and phylogenetic approaches, especially the GMYC model could efficiently assist in resolving issues regarding species boundaries in this fungal group. 


\section{Bibliography}

Al-subhi AM, Al-adawi AO, Van Wyk M, Deadman ML, Wingfield MJ, 2006. Ceratocystis omanensis, a new species from diseased mango trees in Oman. Mycological Research 110, 237-245.

Anderson PK, Cunningham A A, Patel NG, Morales FJ, Epstein PR, Daszak P, 2004 Emerging infectious diseases of plants: pathogen pollution, climate change and agrotechnology drivers. Trends in Ecology and Evolution 19, 535-44.

Baker C J, Harrington TC, Krauss U, Alfenas AC, 2003. Genetic variability and host specialization in the Latin American clade of Ceratocystis fimbriata. Phytopathology 93, 1274-1284.

Baker Engelbrecht CJ, Harrington TC, 2005 Intersterility, morphology and taxonomy of Ceratocystis fimbriata on sweet potato, cacao and sycamore. Mycologia 97, 57-69.

Barnes I, Roux J, Wingfield BD, Dudzinski MJ, Old KM, Wingfield MJ, 2003. Ceratocystis pirilliformis, a new species from Eucalyptus nitens in Australia. Mycologia 95, 865-871.

Barnes I, Nakabonge G, Roux J, Wingfield BD, Wingfield MJ, 2005. Comparison of populations of the wilt pathogen Ceratocystis albifundus in South Africa and Uganda. Plant Patholology 54, 189-195.

Burdon JJ, Thrall PH, Ericson L, 2006. The current and future dynamics of disease in plant communities. Annual Review of Phytopathology 44, 19-39.

Burgess T, Wingfield M J, 2002. Impact of fungal pathogens in natural forest ecosystems: a focus on Eucalyptus. In: Sivasithamparam K, Dixon KW, Barett RL (Eds,) Microorganisms in plant conservation and biodiversity. Kluwer Academic Publishers, pp. 285-306.

Castello JD, Leopold DJ, Smallidge PJ, 1995. Pathogens, patterns, and processes in forest ecosystems. Bioscience 45, 16-24.

Dinoor A, Eshed N. 1984. The role and importance of pathogens in natural plant communities. Annual Review of Phytopathology 22, 443-466.

Dodds P, Thrall P, 2009. Recognition events and host-pathogen co-evolution in gene-for-gene resistance to flax rust. Functional Plant Biology 36, 395-408

Drummond AJ, Rambaut A (2007) BEAST: Bayesian evolutionary analysis by sampling trees. BMC Evolutionary Biology 7, 214. doi:10.1186/1471-2148-7-214

Ezard T, Fujisawa T, Baraclough T, 2009. Species limits by threshold statistics. http://r-forge.rproject.org/projects/splits/

Frank SA, 1992. Models of plant-pathogen coevolution. Trends in Genetics. 8, 213-219. 
Glass NL, Donaldson GC, 1995. Development of primer sets designed for use with the PCR to amplify conserved genes from filamentous Ascomycetes. Applied and Environmental Microbiology 6, 13231330.

Heath RN, Wingfield MJ, Wingfield BD, Meke G, Roux J, 2009. Ceratocystis species on Acacia mearnsii and Eucalyptus spp. in Eastern and Southern Africa including six new species. Fungal Diversity 34, 41-67.

Jacobs K, Bergdahl DR, Wingfield MJ, Halik S, Seifert KA. Bright DE, Wingfield BD, 2004. Leptographium wingfieldii introduced into North America and found associated with exotic Tomicus piniperda and native bark beetles. Mycological Research 108, 411-418.

Johnson JA, Harrington TC, Engelbrecht CJB, 2005. Phylogeny and taxonomy of the North American clade of the Ceratocystis fimbriata complex. Mycologia 97, 1067-1092.

Kamgam Nkuekam G, Jacobs K, De Beer ZW, Wingfield MJ, Roux J, 2008. Ceratocystis and Ophiostoma species, including three new taxa associated with wounds on native South African trees. Fungal Diversity 29, 37-59.

Kamgan Nkuekam G, Wingfield MJ, Mohammed C, Carnegie AJ, Pegg GS, Roux J, 2012a. Ceratocystis species, including two new species associated with nitidulid beetles, on eucalypts in Australia. Antonie van Leeuwenhoek 101, 217-241

Kamgan Nkuekam G, Wingfield MJ, Roux J, 2012b. Ceratocystis species, including two new taxa, from Eucalyptus trees in South Africa. Australian Plant Pathology 42, 283-311.

Katoh K, Kuma K, Toh H, Miyata T, 2005. MAFFT version 5: improvement in accuracy of multiple sequence alignment. Nucleic Acids Research 33, 511-518.

Moller WJ, De Vay JE, 1968. Carrot as species-selective isolation medium for Ceratocystis fimbriata. Phytopathology 58, 123-126.

Möller EM, Bahnweg G, Sandermann H, Geiger HH, 1992. A simple and efficient protocol for isolation of high molecular weight DNA from filamentous fungi, fruit bodies, and infected plant tissues. Nucleic Acids Research 20, 6115-6116.

Morariu VI, Srinivasan BV, Raykar VC, Duraiswami R, Davis LS, 2008. Automatic online tuning for fast Gaussian summation. Advances in Neural Information Processing Systems 21, 1113-1120.

Morris MJ, Wingfield MJ, de Beer C, 1993. Gummosis and wilt of Acacia mearnsii in South Africa caused by Ceratocystis fimbriata. Plant Patholology 42, 814-817. 
Nag Raj TR, Kendrick WB, 1975. A monograph of Chalara and allied genera. Laurier W (ed), Flora. University Press, Waterloo, Ontario.

Parker IM, Gilbert GS, 2004. The evolutionary ecology of novel plant-pathogen interactions. Annual Review Ecology, Evolution, and Systematics 35, 675-700.

Pons J, Barraclough TG, Gomez-zurita J, Cardoso A, Duran DP, Hazell S, Kamoun S et al., 2006. Sequence-based species delimitation for the DNA taxonomy of undescribed insects. Systematic Biology 55, 595-609.

Posada D, 2008. jModelTest, phylogenetic model averaging. Molecular Biology and Evolution 25, 12531256.

Rambaut A, Drummond AJ, 2009. Tracer v1.5, Available from http,//beast.bio.ed.ac.uk/Tracer

Rayner RW, 1970. A mycological colour chart. Commonwealth Mycological Institute Kew, Surrey and British Mycological Society.

R Development Core Team, 2011. R, A language and environment for statistical computing. R Foundation for Statistical Computing, Vienna, Austria. ISBN 3-900051-07-0, URL http,//www.R-project.org/.

Rodas CA, Roux J, Van Wyk M, Wingfield BD, Wingfield MJ, 2008. Ceratocystis neglecta sp. nov., infecting Eucalyptus trees in Colombia. Fungal Diversity 28, 73-84.

Ronquist F, Huelsenbeck JP 2003. MrBayes 3, Bayesian phylogenetic inference under mixed models. Bioinformatics 19, 1572-1574.

Roux J, Wingfield MJ, Bouillet J-P,Wingfield BD, Alfenas AC, 2000. A serious new wilt disease of Eucalyptus caused by ceratocystis fimbriata in Central Africa. Forest Patholology 30, 175-184.

Roux J, Harrington TC, Steimel JP, Wingfield MJ, 2001a. Genetic variation in the wattle wilt pathogen Ceratocystis albofundus. Mycoscience 42, 327-332.

Roux J, Wingfield MJ, Mujuni Byabashaija D, 2001b. First report of Ceratocystis Wilt of Acacia mearnsii in Uganda. Plant Disease 85, 1029.

Roux J, Meke G, Kanyi B, Mwangi L, Mbaga A, Hunter GC, Nakabonge G, 2005. Diseases of plantation forestry trees in Eastern and Southern Africa. South African Journal of Science 101, 1-5.

Roux J, Heath RN, Labuschagne L, Kamgan Nkuekam K, Wingfield MJ, 2007. Occurrence of the wattle wilt pathogen, Ceratocystis albifundus on native South African trees. Forest Patholology 37, 292302. 
Roux J, Wingfield MJ, 2009. Ceratocystis species, emerging pathogens of non-native plantation Eucalyptus and Acacia species. Southern Forests 71, 115-120.

Roux J, Wingfield MJ, 2013. Ceratocystis species on the African continent, with particular reference to $C$. albifundus, an African species in the C. fimbriata sensu lato species complex. In: Seifert KA, Wingfield MJ (Eds), The Ophiostomatoid Fungi, Expanding Frontiers. Biodiversity Series 12 CBS, Utrecht pp. 131-138.

Réblová M, Gams W, Seifert KA, 2011. Monilochaetes and allied genera of the Glomerellales, and a reconsideration of families in the Microascales. Studies in Mycology 68, 163-191.

Schloss PD, Westcott SL, Ryabin T, Hall JR, Hartmann M, Hollister EB, Lesniewski RA et al., 2009. Introducing mothur, open-source, platform-independent, community-supported software for describing and comparing microbial communities. Applied and Environmental Microbiology 75, 7537-7541.

Schoch CL, Sung G-H, Lopez-Giraldez F, Townsend JP, Miadlikowska J, Hofstetter V et al., 2009. The Ascomycota tree of life, A phylum-wide phylogeny clarifies the origin and evolution of fundamental reproductive and ecological traits. Systematic Biology 58, 224-239.

Stukenbrock EH, Mcdonald BA, 2008. The origins of plant pathogens in agro-ecosystems. Annual Review of Phytopathology 46, 75-100.

Swofford DL, 2002. Phylogenetic Analysis Using Parsimony (*and other methods), Versoin 4. Sinauer Associates (ed). Sunderland, Massachusetts.

Tamura K, Peterson D, Peterson N, Stecher G, Nei M, Kumar S 2011. MEGA5, molecular evolutionary genetics analysis using maximum likelihood, evolutionary distance, and maximum parsimony methods. Molecular Biology and Evolution 28, 2731-2739.

Tarigan M, Roux J, Van Wyk M, Tjahjono B, Wingfield MJ 2010a. A new wilt and die-back disease of Acacia mangium associated with Ceratocystis manginecans and C. acaciivora sp. nov. in Indonesia. South African Journal of Botany 77, 292-304.

Tarigan M, Van Wyk M, Roux J, Tjahjono B, Wingfield MJ, 2010b. Three new Ceratocystis spp. in the Ceratocystis moniliformis complex from wounds on Acacia mangium and A. crassicarpa. Mycoscience 51, 53-67.

Taylor JW, Jacobson D J, Kroken S, Kasuga T, Geiser DM, Hibbett DS, Fisher MC, 2000. Phylogenetic species recognition and species concepts in fungi. Fungal Genetics and Biology 31, 21-32. 
Thomson JN, Burdon JJ, 1992. Gene-for gene coevolution between plant and parasites. Nature 360, 121125.

Upadhyay HP 1981. A monograph of Ceratocystis and Ceratocystiopsis. University of Georgia Press, Athens, Georgia.

Van Wyk M, Roux J, Barnes I, Wingfield BD, Chhetri DB, Kirisits T, Wingfield MJ, 2004a. Ceratocystis bhutanensis sp. nov., associated with the bark beetle Ips schmutzenhoferi on Picea spinulosa in Bhutan. Studies in Mycology 50, 365-379.

Van Wyk M, Roux J, Barnes I, Wingfield BD, Liew ECY, Assa B, Summerell BA et al., 2004b. Ceratocystis polychroma sp. nov., a new species from Syzygium aromaticum in Sulawesi. Studies in Mycology 50, 273-282.

Van Wyk M, Roux J, Barnes I, Wingfield BD, Wingfield MJ, 2006a. Molecular phylogeny of the Ceratocystis moniliformis complex and description of C. tribiliformis sp. nov. Fungal Diversity 21, 181-201.

Van Wyk M, Van Der Merve NA, Roux J, Wingfield BD, Kamgam Nkuekam G, Wingfield MJ, 2006b. Population genetic analyses suggest that the eucalyptus fungal pathogen Ceratocystis fimbriata has been introduced into South Africa. South African Journal of Science 102, 259-263.

Van Wyk M, Al Adawi AO, Khan IA, Deadman ML, Al Jahwari AA, Wingfield BD, Ploetz R, et al., 2007a. Ceratocystis manginecans sp. nov., causal agent of a destructive mango wilt disease in Oman and Pakistan. Fungal Diversity 27, 213-230.

Van Wyk M, Pegg G, Lawson S, Wingfield MJ, 2007b. Ceratocystis atrox sp. nov. associated with Phoracantha acanthocera infestations on Eucalyptus grandis in Australia. Australian Plant Patholology 36, 407-414.

Van Wyk M, Wingfield BD, Clegg PA, Wingfield MJ, 2009a. Ceratocystis larium sp. nov., a new species from Styrax benzoin wounds associated with incense harvesting in Indonesia. Persoonia 22, 75-82.

Van Wyk M, Wingfield BD, Marin M, Wingfield MJ, 2009b. Ceratocystis fimbriatomima, a new species in the C. fimbriata sensu lato complex isolated from Eucalyptus trees in Venezuela. Fungal Diversity 34, 173-183.

Van Wyk M, Wingfield BD, Marin M, Wingfield MJ, 2010. New Ceratocystis species infecting coffee, cacao, citrus and native trees in Colombia. Fungal Diversity 40, 103-117.

Van Wyk M, Wingfield BD, Al-adawi AO, Rossetto CJ, Ito MF, Wingfield MJ, 2011a. Two new Ceratocystis species associated with mango disease in Brazil. Mycotaxon 117, 381-404. 
Van Wyk M, Wingfield BD, Wingfield MJ, 2011b. Four new Ceratocystis spp. associated with wounds on Eucalyptus, Schizolobium and Terminalia trees in Ecuador. Fungal Diversity 46, 111-131.

Van Wyk M, Roux J, Kamgan Nkuekam G, Wingfield BD, Wingfield MJ, 2012. Ceratocystis eucalypticola sp. nov. from Eucalyptus in south Africa and comparison to global isolates from this tree. IMA FUNGUS 3, 45-58.

Van Wyk M, Wingfield BD, Wingfield MJ, 2013.Ceratocystis species in the Ceratocystis fimbriata complex. In: Seifert KA, Wingfield MJ (Eds), The Ophiostomatoid Fungi, Expanding Frontiers. Biodiversity Series 12 CBS, Utrecht. pp. 65-76.

White TJ, Bruns T, Lee S, Taylor J, 1990. Amplification and direct sequencing of fungal ribosomal RNA genes for phylogenetics. In: Innis MA, Gelfand DH, Sninsky JJ, White TJ (Eds), PCR Protocols, a guide to methods and applications. Academic Press, New York, pp. 230-257.

Wingfield BD, Van Wyk M, Roos H, Wingfield MJ, 2013. Ceratocystis, emerging evidence for discrete generic boundaries. In: Seifert KA, de Beer ZW, Wingfield MJ (Eds), The Ophiostomatoid Fungi, Expanding Frontiers. Biodiversity Series 12 CBS, Utrecht, the Netherlands. pp. 57-64.

Wingfield MJ, de Beer C, Visser C, Wingfield BD 1996. A New Ceratocystis species defined using morphological and ribosomal DNA sequence comparisons. Systematic and Appl Microbiology 19, 191-202.

Yuan ZQ, Mohammed C, 2002. Ceratocystis moniliformopsis sp. nov., an early colonizer of Eucalyptus obliqua logs in Tasmania, Australia. Australian Systematic Botany 15, 125-133. 
Table 1. List of Ceratocystis species included in this study. Material highlighted in bold were used to generate new sequence data.

\begin{tabular}{|c|c|c|c|c|c|c|c|c|c|}
\hline \multirow{2}{*}{ Species } & \multirow{2}{*}{\multicolumn{2}{|c|}{ Isolate no }} & \multicolumn{3}{|c|}{ Gene region/GeneBank accession no } & \multirow{2}{*}{ Host (or substrate) } & \multirow{2}{*}{$\begin{array}{l}\text { Geographic } \\
\text { origin }\end{array}$} & \multirow{2}{*}{ Collectors } & \multirow{2}{*}{ Relevant references } \\
\hline & & & ITS & BT & TFF & & & & \\
\hline \multicolumn{10}{|c|}{ Ceratocystis fimbriata complex } \\
\hline C. acaciivora & CMW22562 & & EU588655 & EU588635 & EU588645 & Acacia mangium & Indonesia & M. Tarigan & Tarigan et al. (2010a) \\
\hline C. acaciivora & CMW22563 & & EU588656 & EU588636 & EU588646 & Acacia mangium & Indonesia & M. Tarigan & Tarigan et al. (2010a) \\
\hline C. albifundus & CMW5329 & & AF388947 & DQ371649 & EF070401 & Acacia mearnsii & Uganda & J. Roux & Roux et al.(2001b) \\
\hline C. albifundus & CMW23825 & CBS119681 & EU245010 & EU244982 & EU244942 & Acacia mearnsii & South Africa & R.N. Heath & Heath et al. (2009) \\
\hline C. albifundus & CMW37312 & & KC691452 & KC691476 & KC691500 & Terminalia sericea & South Africa & M. Mbenoun \& J. Roux & Present study \\
\hline C. albifundus & CMW37313 & & KC691453 & KC691477 & KC691501 & Combretum zeyheri & South Africa & M. Mbenoun \& J. Roux & Present study \\
\hline C. atrox & CMW19383 & CBS 120517 & EF070414 & EF070430 & EF070402 & Eucalyptus grandis & Australia & M.J. Wingfield & Van Wyk et al. (2007b) \\
\hline C. atrox & CMW19385 & CBS 120518 & EF070415 & EF070431 & EF070403 & Eucalyptus grandis & Australia & M.J. Wingfield & Van Wyk et al. (2007b) \\
\hline C. cacaofunesta & CMW15051 & CBS 152.62 & DQ520636 & DQ520636 & EF070398 & Theobroma cacao & Costa Rica & A.J. Hansen & Baker Engelbrecht \& Harrington (2005) \\
\hline C. cacaofunesta & CMW14809 & CBS 115169 & DQ520637 & EF070428 & EF070399 & Theobroma cacao & Ecuador & C. Suarez & Baker Engelbrecht \& Harrington (2005) \\
\hline C. caryae & CMW14793 & CBS 114716 & EF070424 & EF070439 & EF070412 & Carya cordiformis & USA & J. Johnson & Johnson et al. (2005) \\
\hline C. caryae & CMW14808 & CBS 115168 & EF070423 & EF070440 & EF070411 & Carya ovata & USA & J. Johnson & Johnson et al. (2005) \\
\hline C. colombiana & CMW5751 & CBS 121792 & AY177233 & AY177225 & EU241493 & Coffea arabica & Colombia & M. Marin & Van Wyk et al. (2010) \\
\hline C. colombiana & CMW9572 & & AY233863 & AY233871 & EU241488 & Citrus reticulata (Mandarin) & Colombia & M. Marin & Van Wyk et al. (2010) \\
\hline C. corymbiicola & CMW29120 & CBS 127215 & HM071902 & HM071914 & HQ236453 & Corymbia variegata & Australia & G.K. Kamgan & Kamgan Nkuekam et al. (2012a) \\
\hline C. corymbiicola & CMW29349 & CBS 127216 & HM071919 & HQ236455 & HM071905 & Eucalyptus pilularis & Australia & G.K. Kamgan & Kamgan Nkuekam et al. (2012a) \\
\hline C. curvata & CMW22433 & CBS 122513 & FJ151438 & FJ151450 & FJ151472 & Eucalyptus deglupta & Ecuador & M.J. Wingfield & Van Wyk et al. (2011b) \\
\hline C. curvata & CMW22435 & CBS 122604 & FJ151437 & FJ151449 & FJ151471 & Eucalyptus deglupta & Ecuador & M.J. Wingfield & Van Wyk et al. (2011b) \\
\hline C. diversiconidia & CMW22445 & CBS 123013 & FJ151440 & FJ151452 & FJ151474 & Terminalia ivorensis & Ecuador & M.J. Wingfield & Van Wyk et al. (2011b) \\
\hline C. diversiconidia & CMW22447 & CBS 122818 & FJ151442 & FJ151454 & FJ151476 & Terminalia ivorensis & Ecuador & M.J. Wingfield & Van Wyk et al. (2011b) \\
\hline C. eucalypticola & CMW10000 & CBS 124019 & FJ236722 & FJ236782 & FJ236752 & Eucalyptus sp. & South Africa & M. Van Wyk \& J. Roux & Van Wyk et al. (2012) \\
\hline C. eucalypticola & CMW11536 & CBS 124016 & FJ236723 & FJ236783 & FJ236753 & Eucalyptus sp. & South Africa & M. Van Wyk \& J. Roux & Van Wyk et al. (2012) \\
\hline C. ecuadoriana & CMW22092 & CBS 124020 & FJ151432 & FJ151444 & FJ151466 & Eucalyptus deglupta & Ecuador & M. Van Wyk \& J. Roux & Van Wyk et al. (2011b) \\
\hline C. ecuadoriana & CMW22093 & CBS 124021 & FJ151433 & FJ151445 & FJ151467 & Eucalyptus deglupta & Ecuador & M. Van Wyk \& J. Roux & Van Wyk et al. (2011b) \\
\hline C. fimbriata s.s & CMW1547 & CBS 123010 & AF264904 & EF070443 & EF070395 & Ipomoea batatas & Papua N. G. & E.C.H. McKenzie & $\begin{array}{l}\text { Roux et al. 2000, Van Wyk et al. } \\
\text { (2007a) }\end{array}$ \\
\hline C. fimbriata s.s & CMW15049 & CBS 141.37 & DQ520629 & EF070442 & EF070394 & Ipomoea batatas & USA & C.F. Andrus & Van Wyk et al. (2006b, 2007a) \\
\hline C. fimbriatomima & CMW24174 & CBS 121786 & EF190963 & EF190951 & EF190957 & Eucalyptus sp. & Venezuela & M.J. Wingfield & Van Wyk et al. (2009b) \\
\hline
\end{tabular}




\begin{tabular}{|c|c|c|c|c|c|c|c|c|c|}
\hline \multirow{2}{*}{ Species } & \multirow{2}{*}{\multicolumn{2}{|c|}{ Isolate no }} & \multicolumn{3}{|c|}{ Gene region/GeneBank accession no } & \multirow{2}{*}{ Host (or substrate) } & \multirow{2}{*}{$\begin{array}{l}\text { Geographic } \\
\text { origin }\end{array}$} & \multirow{2}{*}{ Collectors } & \multirow{2}{*}{ Relevant references } \\
\hline & & & ITS & $\mathrm{BT}$ & TFF & & & & \\
\hline C. fimbriatomima & CMW24176 & CBS 121787 & EF190964 & EF190952 & EF190958 & Eucalyptus sp. & Venezuela & M.J. Wingfield & Van Wyk et al. (2009b) \\
\hline C. larium & CMW25434 & CBS 122512 & EU881906 & EU881894 & EU881900 & Styrax benzoin & Indonesia & M.J. Wingfield & Van Wyk et al. (2009a) \\
\hline C. larium & CMW25435 & CBS 122606 & EU881907 & EU881895 & EU881901 & Styrax benzoin & Indonesia & M.J. Wingfield & Van Wyk et al. (2009a) \\
\hline C. mangicola & CMW14797 & CBS 114721 & AY953382 & EF433307 & EF433316 & Mangifera indica & Brazil & C.J. Baker & Van Wyk et al. (2011a) \\
\hline C. mangicola & CMW27306 & & FJ200256 & FJ200269 & FJ200282 & Mangifera indica & Brazil & C.J. Rosetto & Van Wyk et al. (2011a) \\
\hline C. manginecans & CMW13851 & CBS 121659 & AY953383 & EF433308 & EF433317 & Mangifera indica & Oman & A.O. Al Adawi & Van Wyk, et al. (2007a) \\
\hline C. manginecans & CMW13852 & CBS 121660 & AY953384 & EF433309 & EF433318 & Mangifera indica & Oman & A.O. Al Adawi & Van Wyk et al. (2007a) \\
\hline C. mangivora & CMW27305 & CBS 128340 & FJ200262 & FJ200275 & FJ200288 & Mangifera indica & Brazil & C.J. Rosetto & Van Wyk et al. (2011a) \\
\hline C. mangivora & CMW27304 & CBS 127204 & FJ200261 & FJ200274 & FJ200287 & Mangifera indica & Brazil & M. Barreto Figueiredo & Van Wyk et al. (2011a) \\
\hline C. neglecta & CMW17808 & CBS 121789 & EF127990 & EU881898 & EU881904 & Eucalyptus sp. & Colombia & C. Rodas \& J. Roux & Rodas et al. (2008) \\
\hline C. neglecta & CMW18194 & CBS 121017 & EF127991 & EU881899 & EU881905 & Eucalyptus sp. & Colombia & C. Rodas \& J. Roux & Rodas et al. (2008) \\
\hline C. obpyriformis & CMW23807 & CBS 122608 & EU245004 & EU244976 & EU244936 & Acacia mearnsii & South Africa & R.N. Heath & Heath et al. (2009) \\
\hline C. obpyriformis & CMW23808 & CBS 122511 & EU245003 & EU244975 & EU244935 & Acacia mearnsii & South Africa & R.N. Heath & Heath et al. (2009) \\
\hline C. papillata & CMW8856 & CBS 121793 & AY233867 & AY233874 & EU241484 & Citrus limon & Colombia & M.J. Wingfield & Van Wyk et al. (2010) \\
\hline C.papillata & CMW10844 & & AY177238 & AY177229 & EU241481 & Coffea arabica & Colombia & M.J. Wingfield & Van Wyk et al. (2010) \\
\hline C. pirilliformis & CMW6569 & & AF427104 & DQ371652 & AY528982 & Eucalyptus nitens & Australia & M.J. Wingfield & Barnes et al. (2003) \\
\hline C. pirilliformis & CMW6579 & CBS 118128 & AF427105 & DQ371653 & AY528983 & Eucalyptus nitens & Australia & M.J. Wingfield & Barnes et al. (2003) \\
\hline C. platani & CMW14802 & CBS 115162 & DQ520630 & EF070425 & EF070396 & Platanus occidentalis & USA & T.C. Harrington & Baker Engelbrecht \& Harrington (2005) \\
\hline C. platani & CMW23918 & & EF070426 & EF070397 & EU426554 & Platanus sp. & Greece & M.J. Wingfield & Van Wyk et al. $(2006 b, 2007 a)$ \\
\hline C. polychroma & CMW11424 & CBS 115778 & AY528970 & AY528966 & AY528978 & Syzygium aromaticum & Indonesia & M.J. Wingfield & Van Wyk et al. (2004b) \\
\hline C. polychroma & CMW11436 & CBS 115777 & AY528971 & AY528967 & AY528979 & Syzygium aromaticum & Indonesia & M.J. Wingfield & Van Wyk et al. (2004b) \\
\hline C. polyconidia & CMW23809 & CBS 122289 & EU245006 & EU244978 & EU244938 & Acacia mearnsii & South Africa & R.N. Heath & Heath et al. (2009) \\
\hline C. polyconidia & CMW23818 & CBS 122290 & EU245007 & EU244979 & EU244939 & Acacia mearnsii & South Africa & R.N. Heath & Heath et al. (2009) \\
\hline C. populicola & CMW14789 & CBS 119.78 & EF070418 & EF070434 & EF070406 & Populus sp. & Poland & J. Gremmen & Johnson et al. (2005) \\
\hline C. populicola & CMW14819 & CBS 114725 & EF070419 & EF070435 & EF070407 & Populus sp. & USA & T. Hints & Johnson et al. (2005) \\
\hline C. smalleyi & CMW14800 & CBS 114724 & EF070420 & EF070436 & EF070408 & Carya cordiformis & USA & G. Smalley & Johnson et al. (2005) \\
\hline C. smalleyi & CMW26383 & CBS 114724 & EU426553 & EU426555 & EU426556 & Carya cordiformis & USA & Unknown & Johnson et al. (2005) \\
\hline C. tanganyicensis & CMW15991 & CBS 122295 & EU244997 & EU244969 & EU244929 & Acacia mearnsii & Tanzania & R.N. Heath \& J. Roux & Heath et al. (2009) \\
\hline C. tanganyicensis & CMW15999 & CBS 122294 & EU244998 & EU244970 & EU244939 & Acacia mearnsii & Tanzania & R.N. Heath \& J. Roux & Heath et al. (2009) \\
\hline C. thulamelensis & CMW35970 & & KC691454 & KC691478 & KC691502 & Combretum zeyheri & South Africa & M. Mbenoun \& J. Roux & Present study \\
\hline C. thulamelensis & CMW35971 & CBS 131283 & KC691455 & КС691479 & KC691503 & Combretum zeyheri & South Africa & M. Mbenoun \& J. Roux & Present study \\
\hline
\end{tabular}




\begin{tabular}{|c|c|c|c|c|c|c|c|c|c|}
\hline \multirow{3}{*}{$\begin{array}{c}\text { Species } \\
\text { C. thulamelensis }\end{array}$} & \multirow{2}{*}{\multicolumn{2}{|c|}{ Isolate no }} & \multicolumn{3}{|c|}{ Gene region/GeneBank accession no } & \multirow{3}{*}{$\begin{array}{l}\text { Host (or substrate) } \\
\text { Colophospermum mopane }\end{array}$} & \multirow{3}{*}{$\begin{array}{l}\text { Geographic } \\
\text { origin } \\
\text { South Africa }\end{array}$} & \multirow{3}{*}{$\begin{array}{l}\text { Collectors } \\
\text { M. Mbenoun \& J. Roux }\end{array}$} & \multirow{3}{*}{$\begin{array}{l}\text { Relevant references } \\
\text { Present study }\end{array}$} \\
\hline & & & \multirow{2}{*}{$\begin{array}{c}\text { ITS } \\
\text { KC691456 }\end{array}$} & \multirow{2}{*}{$\begin{array}{c}\text { BT } \\
\text { KC691480 }\end{array}$} & \multirow{2}{*}{$\begin{array}{c}\text { TFF } \\
\text { KC691504 }\end{array}$} & & & & \\
\hline & CMW35972 & CBS 131284 & & & & & & & \\
\hline C. thulamelensis & CMW35973 & & KC691457 & KC691481 & KC691505 & Colophospermum mopane & South Africa & M. Mbenoun \& J. Roux & Present study \\
\hline C. tsitsikammensis & CMW14276 & CBS 121018 & EF408555 & EF408569 & EF408576 & Rapanea melanophloeos & South Africa & G.N. Kamgan \& J. Roux & Kamgan et al. (2008) \\
\hline C. tsitsikammensis & CMW14278 & CBS 121019 & EF408556 & EF408570 & EF408577 & Rapanea melanophloeos & South Africa & G.N. Kamgan \& J. Roux & Kamgan et al. (2008) \\
\hline C. variospora & CMW20935 & CBS 114715 & EF070421 & EF070437 & EF070409 & Quercus alba & USA & J. Johnson & Johnson et al. (2005) \\
\hline C. variospora & CMW20936 & CBS 114714 & EF070422 & EF070438 & EF070410 & Quercus robur & USA & J. Johnson & Johnson et al. (2005) \\
\hline C. zambeziensis & CMW35958 & CBS 131280 & KC691458 & KC691482 & KC691506 & Combretum imberbe & South Africa & M. Mbenoun \& J. Roux & Present study \\
\hline C. zambeziensis & CMW35959 & & KC691459 & KC691483 & KC691507 & Combretum imberbe & South Africa & M. Mbenoun \& J. Roux & Present study \\
\hline C. zambeziensis & CMW35962 & & KC691460 & KC691484 & KC691508 & Schotia brachypetala & South Africa & M. Mbenoun \& J. Roux & Present study \\
\hline C. zambeziensis & CMW35963 & CBS 131282 & КС691461 & KC691485 & KC691509 & Acacia nigrescens & South Africa & M. Mbenoun \& J. Roux & Present study \\
\hline \multicolumn{10}{|c|}{ Ceratocystis moniliformis complex } \\
\hline C. bhutanensis & CMW8217 & CBS 114289 & AY528957 & AY528962 & AY528952 & Picea spinulosa & Bhutan & T. Kirisits \& D.B.Chhetri & Van Wyk et al. (2004a) \\
\hline C. bhutanensis & CMW8242 & CBS 112907 & AY528956 & AY528961 & AY528951 & Picea spinulosa & Bhutan & T. Kirisits \& D.B.Chhetri & Van Wyk et al. (2004b) \\
\hline C. cryptoformis & CMW36826 & CBS 131277 & KC691462 & KC691486 & KC691510 & Terminalia sericea & South Africa & M. Mbenoun \& J. Roux & Present study \\
\hline C. cryptoformis & CMW36827 & & KC691463 & KC691487 & KC691511 & Combretum zeyheri & South Africa & M. Mbenoun \& J. Roux & Present study \\
\hline C. cryptoformis & CMW36828 & CBS 131279 & КC691464 & KC691488 & KC691512 & Ziziphus mucronata & South Africa & M. Mbenoun \& J. Roux & Present study \\
\hline C. cryptoformis & CMW36870 & & KC691465 & KC691489 & KC691513 & Combretum hereroense & South Africa & M. Mbenoun \& J. Roux & Present study \\
\hline C. decipiens & CMW25914 & CBS 129737 & HQ203219 & HQ203236 & HQ236438 & Eucalyptus maculata & South Africa & G.N. Kamgan \& J. Roux & Kamgan Nkuekam et al. (2012b) \\
\hline C. decipiens & CMW25918 & CBS 129735 & HQ203218 & HQ203235 & HQ236437 & Eucalyptus cloeziana & South Africa & G.N. Kamgan \& J. Roux & Kamgan Nkuekam et al. (2012b) \\
\hline C. inquinans & CMW21106 & & EU588587 & EU588666 & EU588674 & Acacia mangium & Indonesia & M. Tarigan & Tarigan et al. (2010b) \\
\hline C. inquinans & CMW21107 & CBS 124009 & EU588588 & EU588667 & EU588675 & Acacia mangium & Indonesia & M. Tarigan & Tarigan et al. (2010b) \\
\hline C. microbasis & CMW21115 & CBS 124015 & EU588592 & EU588671 & EU588679 & Acacia mangium & Indonesia & M. Tarigan & Tarigan et al. (2010b) \\
\hline C. microbasis & CMW21117 & CBS 124013 & EU588593 & EU588672 & EU588680 & Acacia mangium & Indonesia & M. Tarigan & Tarigan et al. (2010b) \\
\hline C. moniliformis & CMW4114 & CBS118151 & AY528997 & AY528986 & AY529007 & Shizolobium parahyba & Ecuador & M.J. Wingfield & Van Wyk et al. (2006) \\
\hline C. moniliformis & CMW9590 & CBS116452 & AY431101 & AY528985 & AY529006 & Eucalyptus grandis & South Africa & J. Roux & Van Wyk et al. (2006) \\
\hline C. moniliformopsis & CMW9986 & CBS109441 & AY528998 & AY528987 & AY529008 & Eucalyptus obliqua & Australia & Z.Q. Yuan & Yuan \& Mohammed (2002) \\
\hline C. moniliformopsis & CMW10214 & CBS115792 & AY528999 & AY528988 & AY529009 & Eucalyptus sieberi & Australia & M.J. Dudzinski & Yuan \& Mohammed (2002) \\
\hline C. oblonga & CMW23803 & CBS122291 & EU245019 & EU244991 & EU244951 & Acacia mearnsii & South Africa & R.N. Heath & Heath et al. (2009) \\
\hline C. oblonga & CMW30835 & & HQ203221 & HQ203238 & HQ236440 & Carpophilus dimidiatus & South Africa & G.N. Kamgan \& J. Roux & Kamgan Nkuekam et al. (2012b) \\
\hline C. oblonga & CMW36836 & & КC691466 & KC691490 & KC691514 & Ziziphus mucronata & South Africa & M. Mbenoun \& J. Roux & Present study \\
\hline C. oblonga & CMW36853 & & КC691467 & КС691491 & KC691515 & Colophospermum mopane & South Africa & M. Mbenoun \& J. Roux & Present study \\
\hline
\end{tabular}




\begin{tabular}{|c|c|c|c|c|c|c|c|c|c|}
\hline \multirow{2}{*}{ Species } & \multirow{2}{*}{\multicolumn{2}{|c|}{ Isolate no }} & \multicolumn{3}{|c|}{ Gene region/GeneBank accession no } & \multirow{2}{*}{ Host (or substrate) } & \multirow{2}{*}{$\begin{array}{l}\text { Geographic } \\
\text { origin }\end{array}$} & \multirow{2}{*}{ Collectors } & \multirow{2}{*}{ Relevant references } \\
\hline & & & ITS & $\mathrm{BT}$ & TFF & & & & \\
\hline C. omanensis & CMW3800 & CBS117839 & DQ074743 & DQ074733 & DQ074738 & Mangifera indica & Oman & A.O. Al Adawi & Al-subhi et al. (2006) \\
\hline C. omanensis & CMW11048 & CBS115787 & DQ074742 & DQ074732 & DQ074737 & Mangifera indica & Oman & A.O. Al Adawi & Al-Subhi et al. (2006) \\
\hline C. salinaria & CMW25911 & CBS 129733 & HQ203213 & HQ203230 & HQ236432 & Eucalyptus maculata & South Africa & G.N. Kamgan \& J. Roux & Kamgan Nkuekam et al. (2012b) \\
\hline C. salinaria & CMW30703 & CBS 129734 & HQ203214 & HQ203231 & HQ236433 & Eucalyptus saligna & South Africa & G.N. Kamgan \& J. Roux & Kamgan Nkuekam et al. (2012b) \\
\hline C. savannae & CMW17300 & CBS121151 & EF408551 & EF408565 & EF408572 & Acacia nigrescens & South Africa & G.N. Kamgan \& J. Roux & Kamgan et al. (2008) \\
\hline C. savannae & CMW30828 & & HQ203223 & HQ203240 & HQ236442 & Brachypeplus depressus & South Africa & G.N. Kamgan \& J. Roux & Kamgan Nkuekam et al. (2012)b \\
\hline C. savannae & CMW36829 & & KC691468 & KC691492 & KC691516 & Combretum imberbe & South Africa & M. Mbenoun \& J. Roux & Present study \\
\hline C. savannae & CMW36858 & & KC691469 & KC691493 & KC691517 & Colophospermum mopane & South Africa & M. Mbenoun \& J. Roux & Present study \\
\hline C. sublaevis & CMW22444 & CBS122518 & FJ151430 & FJ151464 & FJ151486 & Terminalia ivorensis & Ecuador & M.J. Wingfield & Van Wyk et al. (2011b) \\
\hline C. sublaevis & CMW22449 & CBS122517 & FJ151431 & FJ151465 & FJ151487 & Terminalia ivorensis & Ecuador & M.J. Wingfield & Van Wyk et al. (2011b) \\
\hline C. sumatrana & CMW21109 & CBS 124011 & EU588589 & EU588668 & EU588676 & Acacia mangium & Indonesia & M. Tarigan & Tarigan et al. (2010b) \\
\hline C. sumatrana & CMW21111 & CBS 124012 & EU588590 & EU588669 & EU588677 & Acacia mangium & Indonesia & M. Tarigan & Tarigan et al. (2010b) \\
\hline C. tribiliformis & CMW13011 & CBS115867 & AY528991 & AY529001 & AY529012 & Pinus merkusii & Indonesia & M.J. Wingfield & Van Wyk et al. (2006) \\
\hline C. tribiliformis & CMW13012 & CBS118242 & AY528992 & AY529002 & AY529013 & Pinus merkusii & Indonesia & M.J. Wingfield & Van Wyk et al. (2006) \\
\hline C. tyalla & CMW28917 & & HM071899 & HM071909 & HQ236448 & Eucalyptus grandis & Australia & G.K. Kamgan & Kamgan Nkuekam et al. (2012a) \\
\hline C. tyalla & CMW28920 & & HM071896 & HM071910 & HQ236449 & Eucalyptus grandis & Australia & G.K. Kamgan & Kamgan Nkuekam et al. (2012a) \\
\hline T. ceramica & CMW15245 & CBS122299 & EU245022 & EU244994 & EU244926 & Eucalyptus grandis & Malawi & R.N. Heath \& J. Roux & Heath et al. (2009) \\
\hline T. ceramica & CMW15248 & CBS122300 & EU245024 & EU244996 & EU244928 & Eucalyptus grandis & Malawi & R.N. Heath \& J. Roux & Heath et al. (2009) \\
\hline \multicolumn{10}{|c|}{ Thielaviopsis thielavioides complex } \\
\hline T. basicola & CMW6714 & & FJ411331 & FJ411357 & FJ411305 & Daucus carota (Carrot) & Australia & & Van Wyk et al. (2009a) \\
\hline T. basicola & CMW25439 & & FJ411334 & FJ411360 & FJ411308 & Styrax benzoin & Indonesia & M.J. Wingfield & Van Wyk et al. (2009a) \\
\hline T. basicola & CMW35968 & & KC691470 & КC691494 & KC691518 & Acacia grandicornuta & South Africa & M. Mbenoun \& J. Roux & Present study \\
\hline T. basicola & CMW35969 & & KC691471 & KC691495 & KC691519 & Acacia grandicornuta & South Africa & M. Mbenoun \& J. Roux & Present study \\
\hline T. basicola & CMW35974 & & KC691472 & KC691496 & KC691520 & Colophospermum mopane & South Africa & M. Mbenoun \& J. Roux & Present study \\
\hline T. ovoidea & CMW22733 & CBS 354.76 & FJ411343 & FJ411369 & FJ411317 & Fire wood & Netherlands & Unknown & Van Wyk et al. (2009a) \\
\hline T.populi & CMW26387 & CBS 484.71 & FJ411336 & FJ411362 & FJ411310 & Populus robusta & Belgium & Unknown & Van Wyk et al. (2009a) \\
\hline T. populi & CMW26388 & CBS 486.71 & FJ411337 & FJ411363 & FJ411311 & Populus gelrica & Belgium & Unknown & Van Wyk et al. (2009a) \\
\hline T. thielavioides & CMW22736 & CBS 148.37 & FJ411342 & FJ411367 & FJ411315 & Lupinus albus & Italy & Unknown & Van Wyk et al. (2009a) \\
\hline T. thielavioides & CMW22737 & CBS 180.75 & FJ411341 & FJ411366 & FJ411314 & Populus sp. & Belgium & Unknown & Van Wyk et al. (2009a) \\
\hline T. thielavioides & CMW37309 & & KC691473 & КC691497 & KC691521 & Pseudolachnostylis sp. & South Africa & M. Mbenoun \& J. Roux & Present study \\
\hline T. thielavioides & CMW37310 & & KC691474 & KC691498 & KC691522 & Philenoptera violacea & South Africa & M. Mbenoun \& J. Roux & Present study \\
\hline
\end{tabular}




\begin{tabular}{|c|c|c|c|c|c|c|c|c|}
\hline \multirow{2}{*}{ Species } & \multirow{2}{*}{ Isolate no } & \multicolumn{3}{|c|}{ Gene region/GeneBank accession no } & \multirow{2}{*}{ Host (or substrate) } & \multirow{2}{*}{$\begin{array}{l}\text { Geographic } \\
\text { origin }\end{array}$} & \multirow{2}{*}{ Collectors } & \multirow{2}{*}{ Relevant references } \\
\hline & & ITS & BT & TFF & & & & \\
\hline T. thielavioides & CMW37311 & KC691475 & KC691499 & KC691523 & Carpophilus hemipterus & South Africa & M. Mbenoun \& J. Roux & Present study \\
\hline C. virescens & CBS123166 & DQ520639 & EF070441 & EF070413 & Fagus americana & USA & D. Houston & Van Wyk et al. (2007b) \\
\hline
\end{tabular}


Table 2. List of tree species from which Ceratocystis species were collected in Kruger National Park.

\begin{tabular}{|c|c|}
\hline Plant family & Tree species \\
\hline ANACARDIACEAE & $\begin{array}{l}\text { Lannea stuhlmannii } \\
\text { Lannea } \text { sp. } \\
\text { Sclerocarya birrea }\end{array}$ \\
\hline CAPPARACEAE & Boscia albitrunca \\
\hline CAESALPINIACEAE & $\begin{array}{l}\text { Cassia abbreviata } \\
\text { Colophospermum mopane } \\
\text { Peltophorum africanum } \\
\text { Schotia brachypetala }\end{array}$ \\
\hline COMBRETACEAE & $\begin{array}{l}\text { Combretum apiculatum } \\
\text { Combretum hereroense } \\
\text { Combretum imberbe } \\
\text { Combretum molle } \\
\text { Combretum zeyheri } \\
\text { Terminalia sericea }\end{array}$ \\
\hline EBENACEAE & Euclea divinorum \\
\hline ERYTHROXYLACEAE & Erythroxylum emarginatum \\
\hline EUPHORBIACEAE & $\begin{array}{l}\text { Croton megalobotrys } \\
\text { Spirostachys africana }\end{array}$ \\
\hline FABACEAE & Philenoptera violacea \\
\hline MIMOSACEAE & $\begin{array}{l}\text { Acacia grandicornuta } \\
\text { Acacia nigrescens } \\
\text { Acacia tortilis } \\
\text { Acacia xanthophloea } \\
\text { Acacia sp. } \\
\text { Albizia harveyi }\end{array}$ \\
\hline RHAMNACEAE & Ziziphus mucronata \\
\hline
\end{tabular}




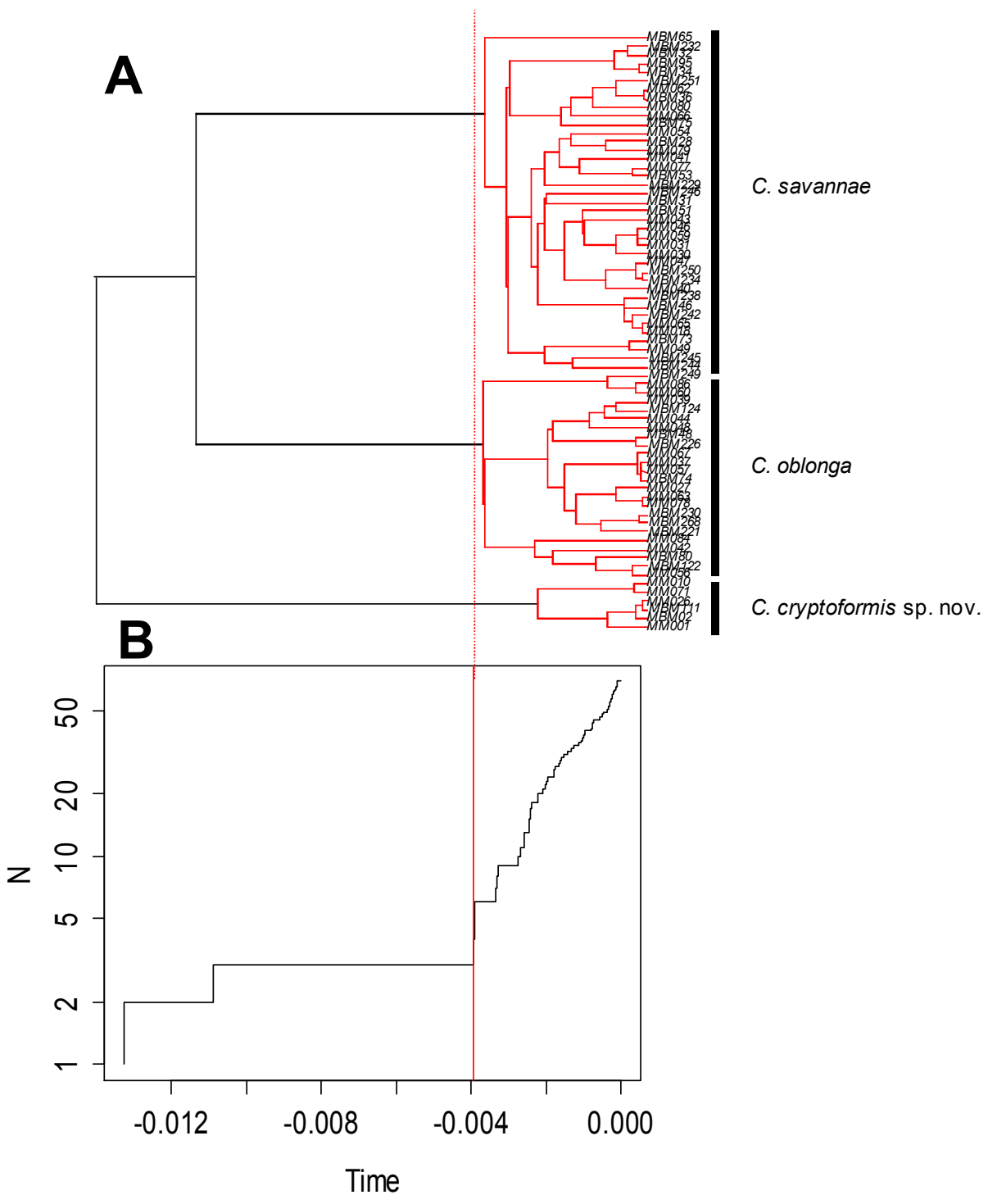

Figure 1. Species delineation in the Ceratocystis moniliformis s.l. group from Kruger National Park based on General Mixed Yule coalescent model. A, Phylogeny based on the $\beta$-tubulin gene obtained from $10^{7}$ generations in BEAST; B, species through time plot showing the transition between speciation and population processes. 


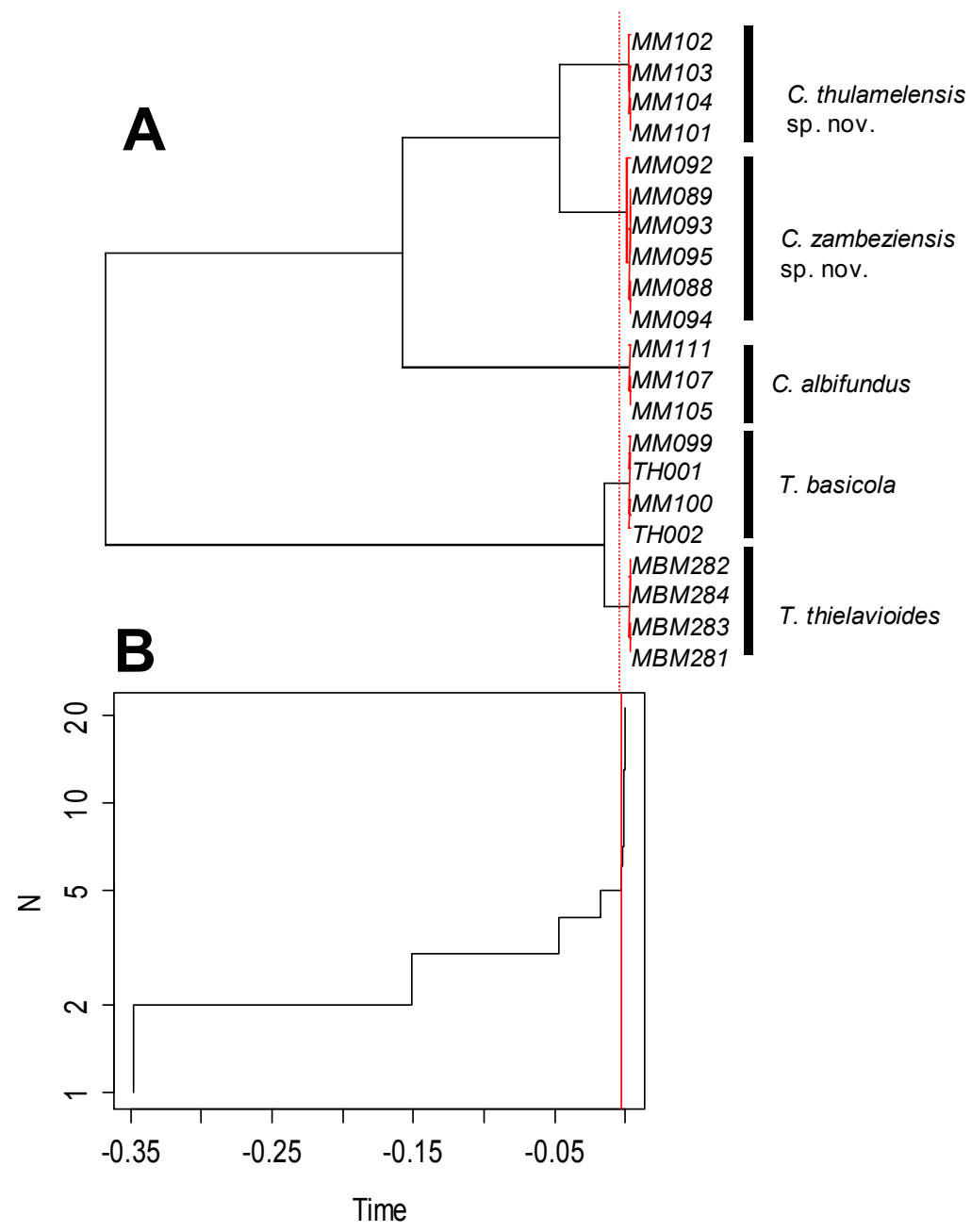

Figure 2. Species delineation in the Ceratocystis fimbriata s.1. and Thielaviopsis thielavioides s.1. groups from Kruger National Park based on General Mixed Yule coalescent model. A, Phylogeny based on the ITS gene obtained from $10^{7}$ generations in BEAST; B, species through time plot showing the transition between speciation and population processes. 


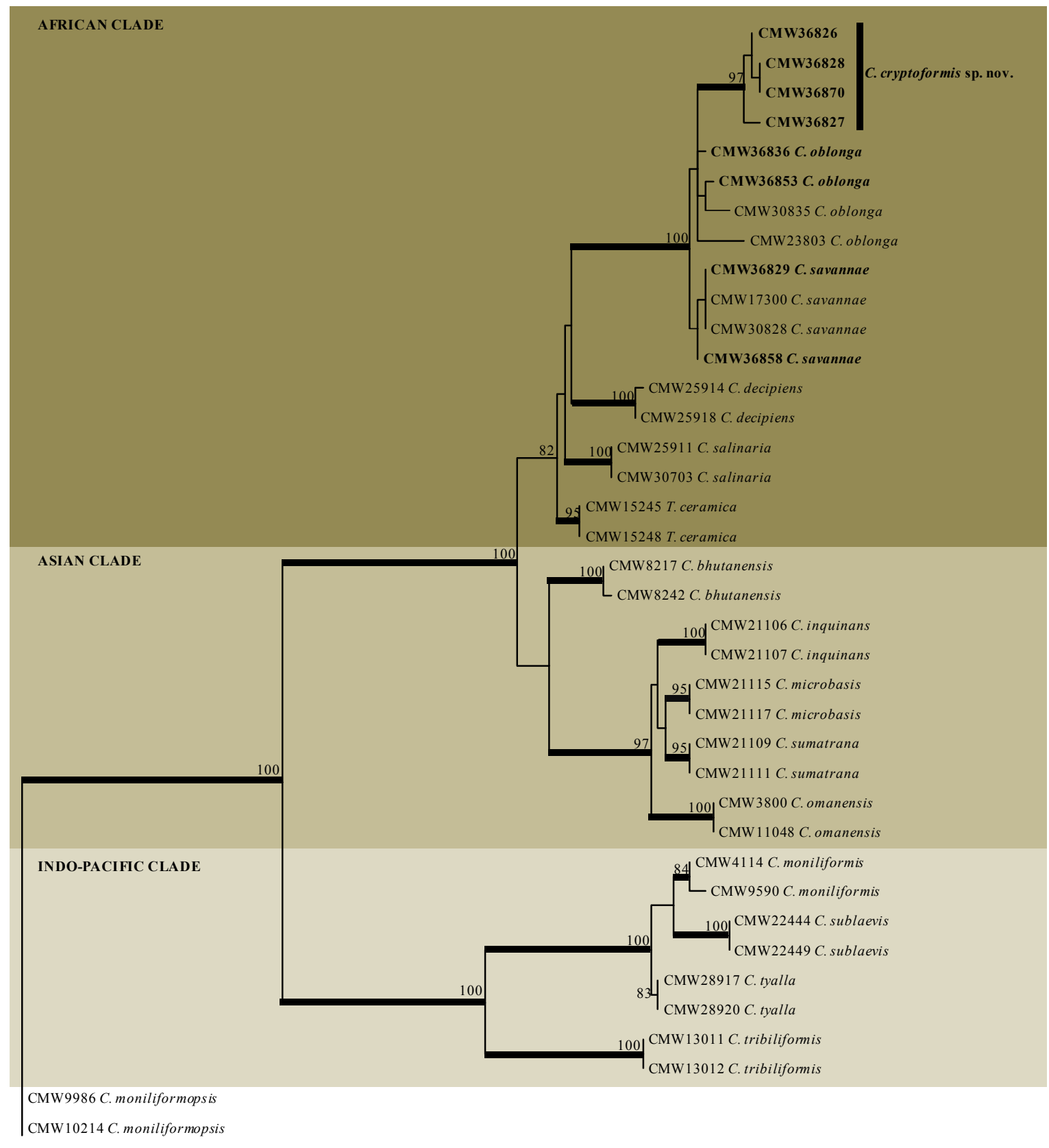

10.0

Figure 3. Most parsimonious tree from 100 heuristic searches with combined ITS, $\beta$-tubulin and TEF- $1 \alpha$ gene sequences showing the position of $C$. cryptoformis sp. nov. in a global phylogeographic scheme of the $C$. moniliformis species complex. Bootstrap values $>70 \%$ from 1000 replicates are indicated above branches. Thick branches are those with $>90 \%$ posterior probability support based on Bayesian, maximum-credibility-consensus trees. Taxa from KNP are highlighted in bold. 


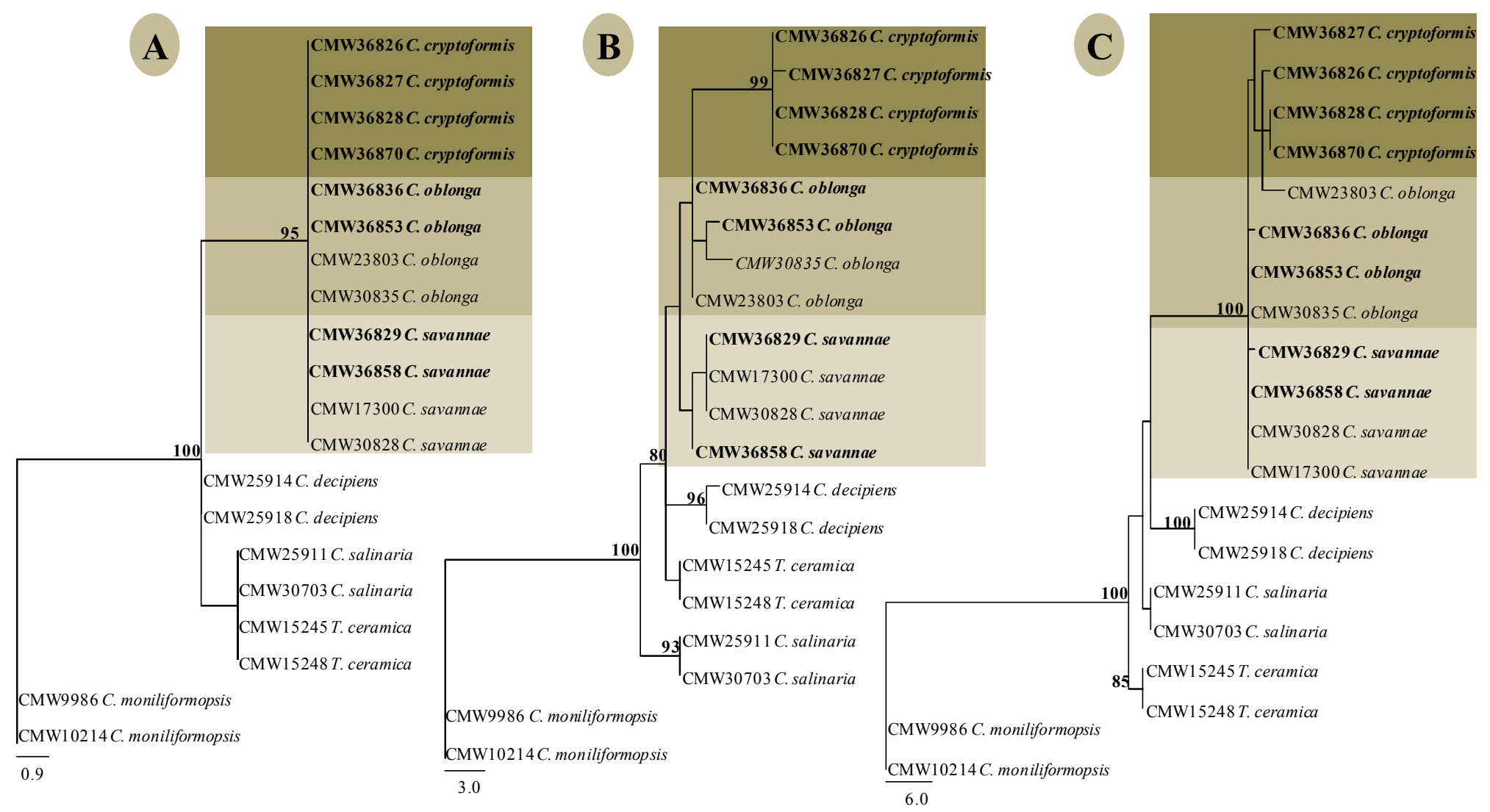

Figure 4. Single-gene most parsimonious trees of the African clade of C. moniliformis s.1. based on A, ITS (Tree \#, 1; TL, 13; CI, 1; RI, 1; RC, 1), B, $\beta$-tubulin (Tree \#, 7; TL, 51; CI, 0.92; RI, 0.95; RC, 0.87) and C, TEF-1 $\alpha$ (Tree \#, 4; TL, 117; CI, 0.94; RI, 0.96; RC, 0.9) sequence data. Isolates from KNP are highlighted in bold. The trees were generated via 100 heuristic searches. Bootstrap values $>70 \%$ from 1000 replicates are indicated above branches. NB, A larger sequence size (786 characters) was used for the TEF-1 $\alpha$ gene. 


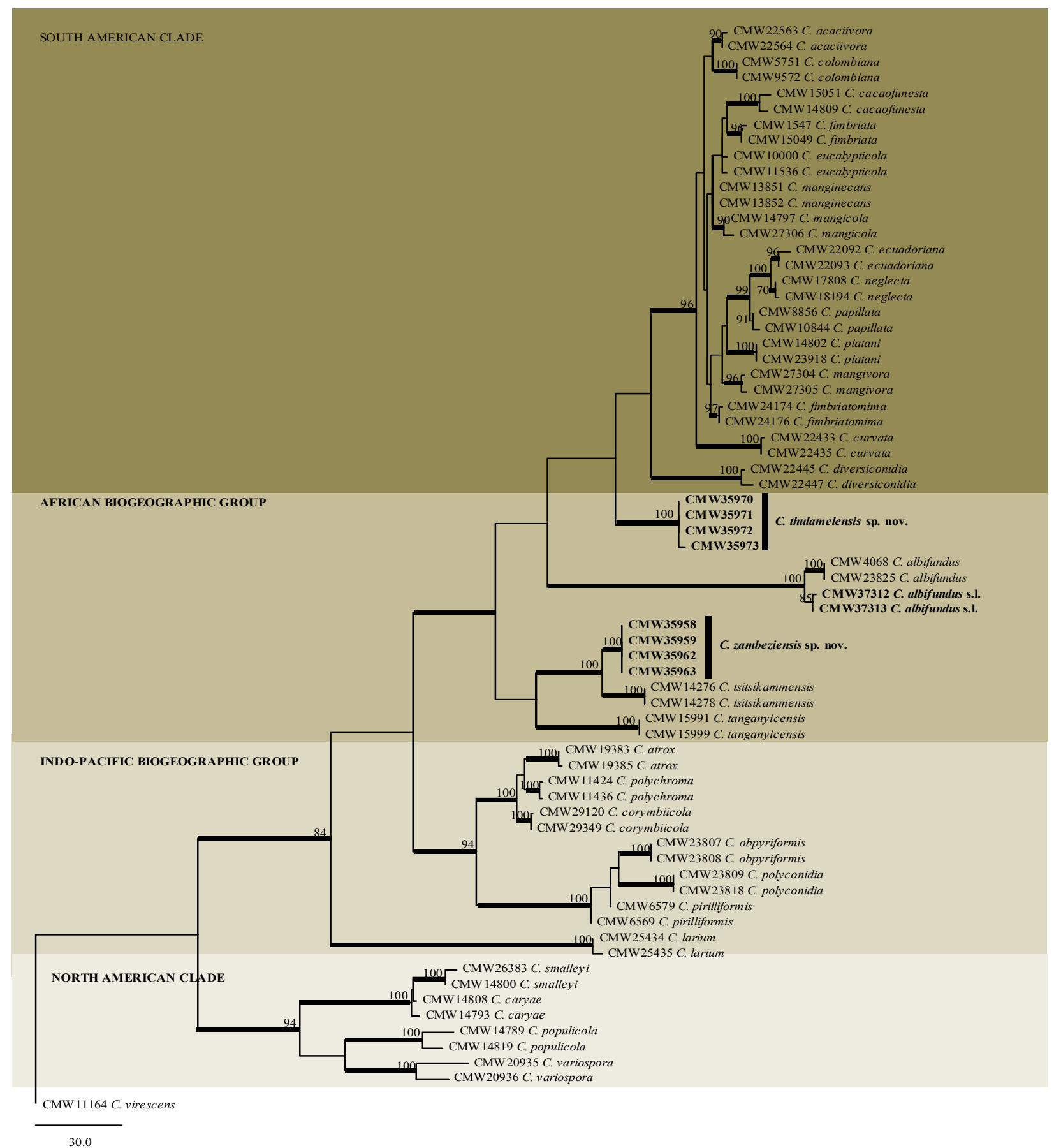

Figure 5. Most parsimonious tree resulting from 100 heuristic searches with combined ITS, $\beta$-tubulin and TEF-1 $\alpha$ gene sequences, showing the position of $C$. thulamelensis sp. nov. and C. zabeziensis sp. nov in a global phylogeographic scheme for the $C$. fimbriata species complex. Bootstrap values $>70 \%$ from 1000 replicates are indicated above branches. Thick branches are those with $>90 \%$ posterior probability support based on Bayesian, maximum-credibility-consensus trees. Taxa from KNP are highlighted in bold. 


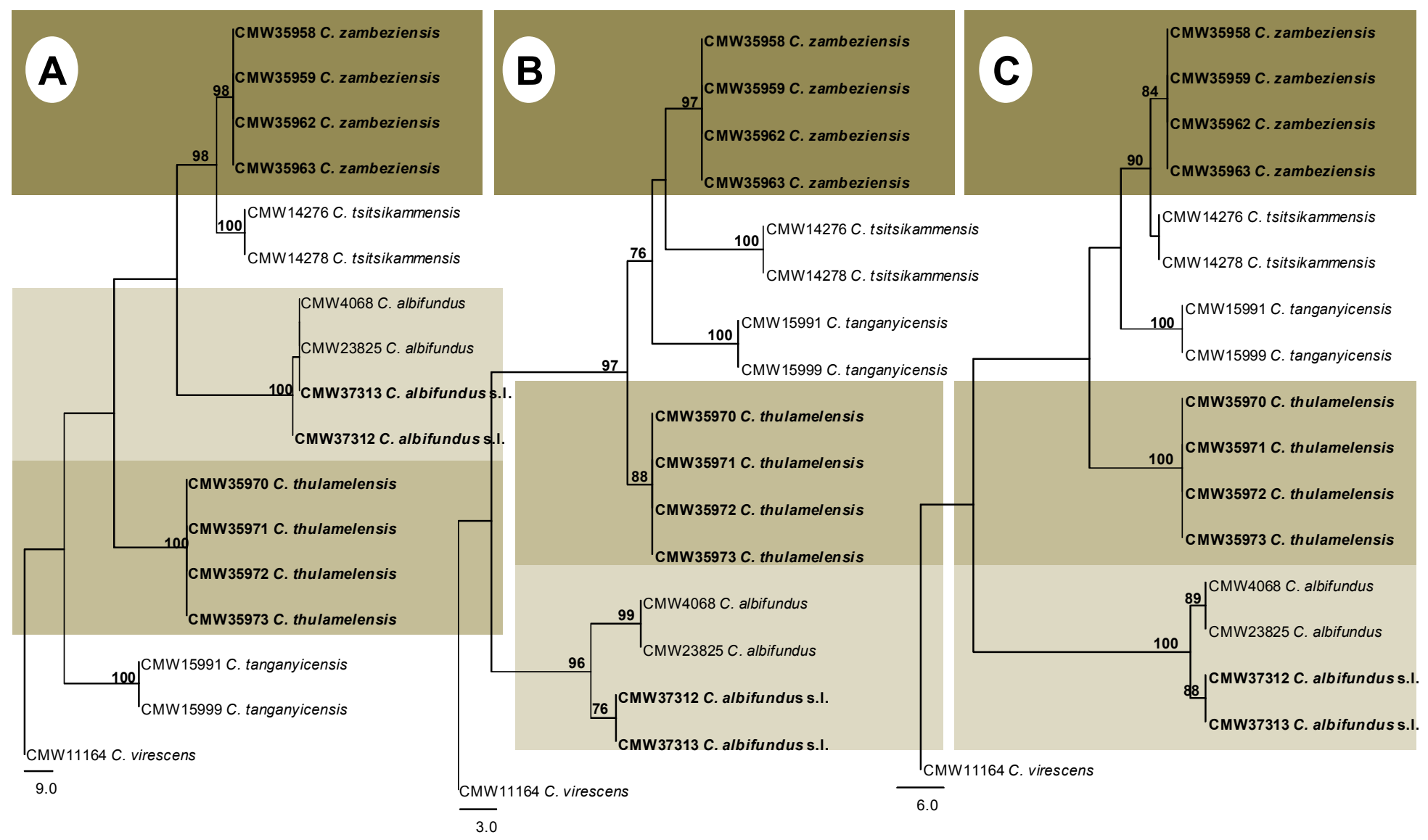

Figure 6. Single-gene most parsimonious trees of the African biogeographic group of C. fimbriata s.1. based on A, ITS (Tree \#, 4; TL, 173; CI, 0.85; RI, 0.94; RC, 0.8), B, $\beta$-tubulin (Tree \#, 1; TL, 65; CI, 0.94; RI, 0.97; RC, 0.91) and C, TEF-1 $\alpha$ (Tree \#, 1; TL, 116; CI, 0.93; RI, 0.97; RC, $0.9)$ sequence data. Isolates from KNP are highlighted and in bold. The trees were generated via 100 heuristic searches. Bootstrap values $>70 \%$ from 1000 replicates are indicated above branches. 


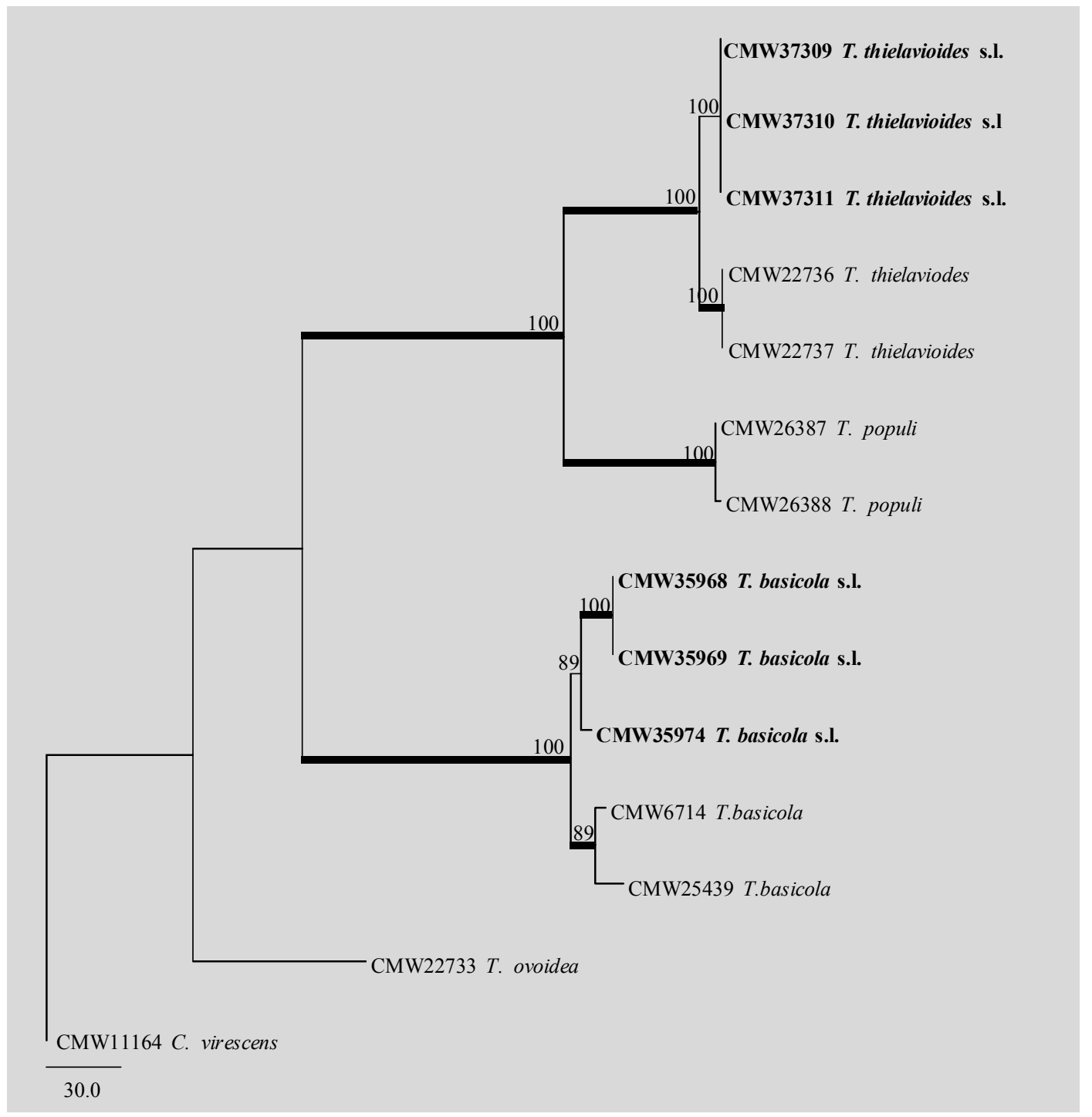

Figure 7. Most parsimonious tree from 100 heuristic searches with combined ITS, $\beta$-tubulin and TEF- $1 \alpha$ gene sequences depicting the relationship between KNP isolates (bold) and references of species in the $T$. thielavioides complex. Bootstrap values $>70 \%$ from 1000 replicates are indicated above branches. Thick branches are those with $>90 \%$ posterior probability support based on Bayesian, maximum-credibilityconsensus trees. 

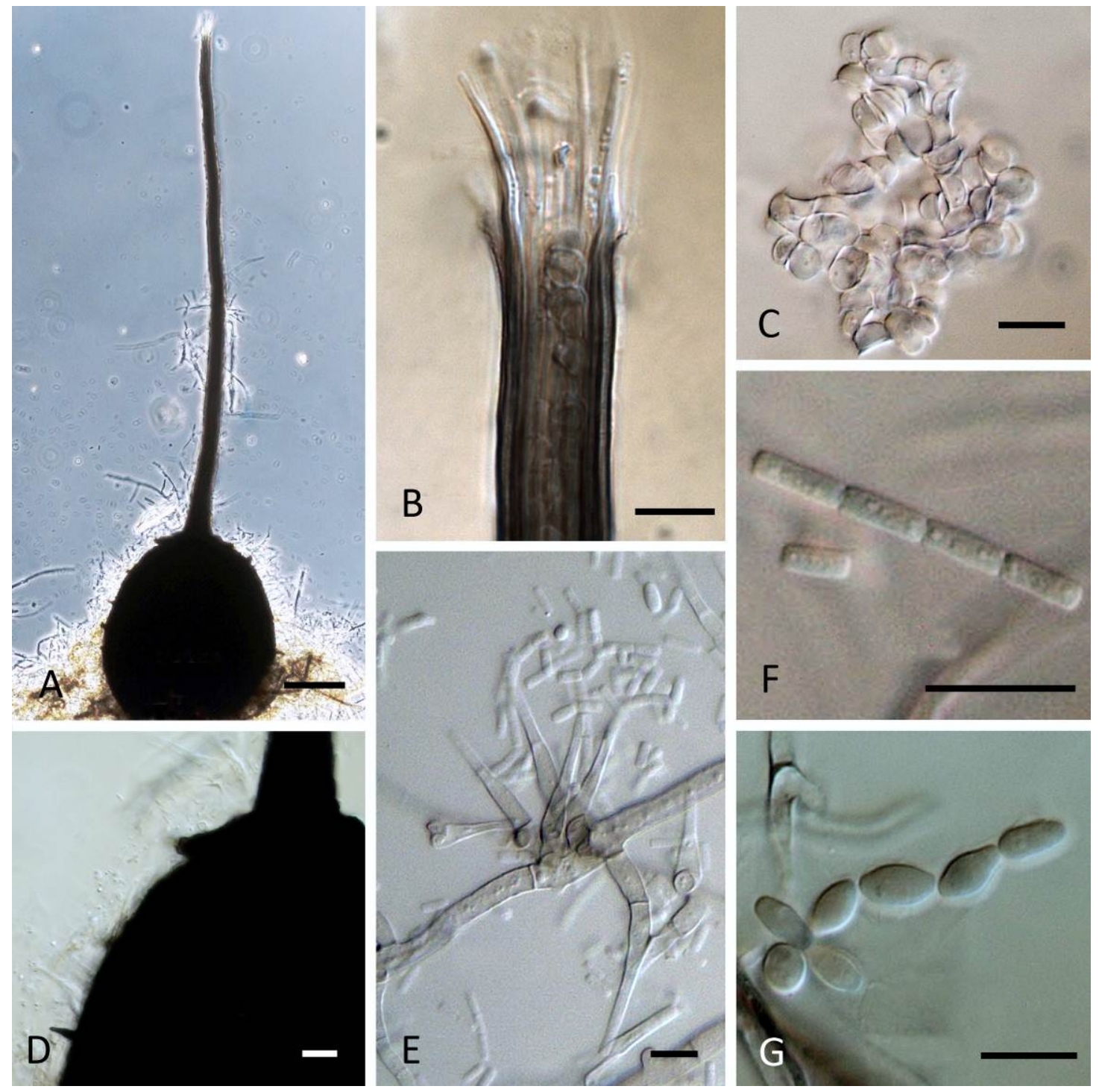

Figure 8. Morphological characteristics of Ceratocystis cryptoformis sp. nov. A, ascomata with globose base and extended neck; B, details of neck tip showing divergent ostiolar hyphae; C, cucullate (hatshaped) ascospores; D, details of ascocarp base showing disciform structure at neck base and conical ornamentations; E, lageniform phialides; F, cylindrical primary conidia; G, diversiform secondary conidia. Scale bars, A: $100 \mu \mathrm{m} ; \mathrm{B}, \mathrm{C}, \mathrm{D}, \mathrm{E}, \mathrm{F}, \mathrm{G}: 10 \mu \mathrm{m}$ 

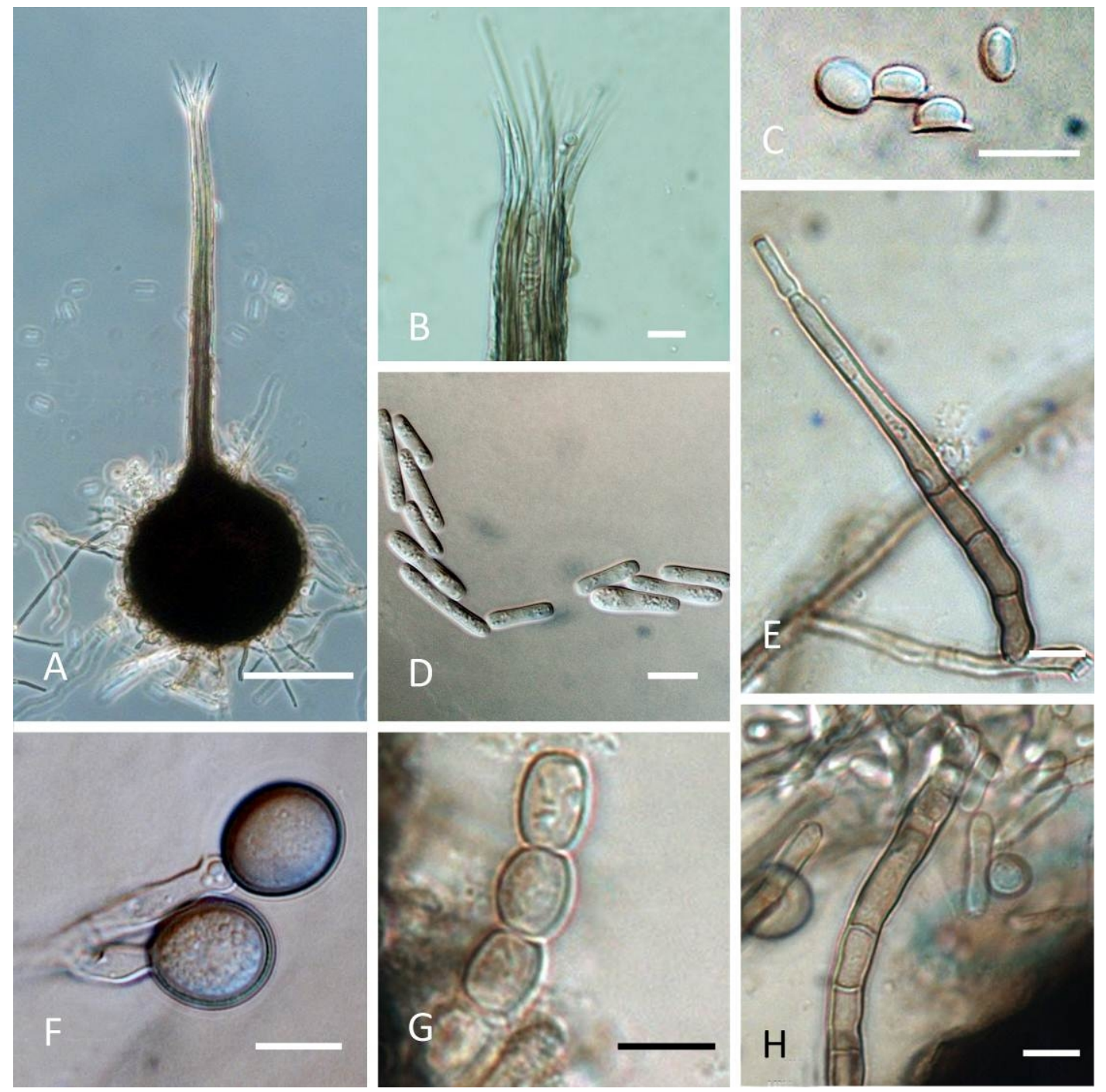

Figure 9. Morphological characteristics of Ceratocystis thulamelensis sp. nov. A, ascomata with globose base and extended neck; B, details of neck tip showing divergent ostiolar hyphae; C, cucullate (hatshaped) ascospores; D, bacilliform primary conidia; E, lageniform phialidic conidiophores; F, globose aleurioconidia; G, oblong secondary conidia; $\mathrm{H}$, flaring secondary conidiophore. Scale bars, A: $100 \mu \mathrm{m}$; B, C, D, E, F, G, H: $10 \mu \mathrm{m}$ 

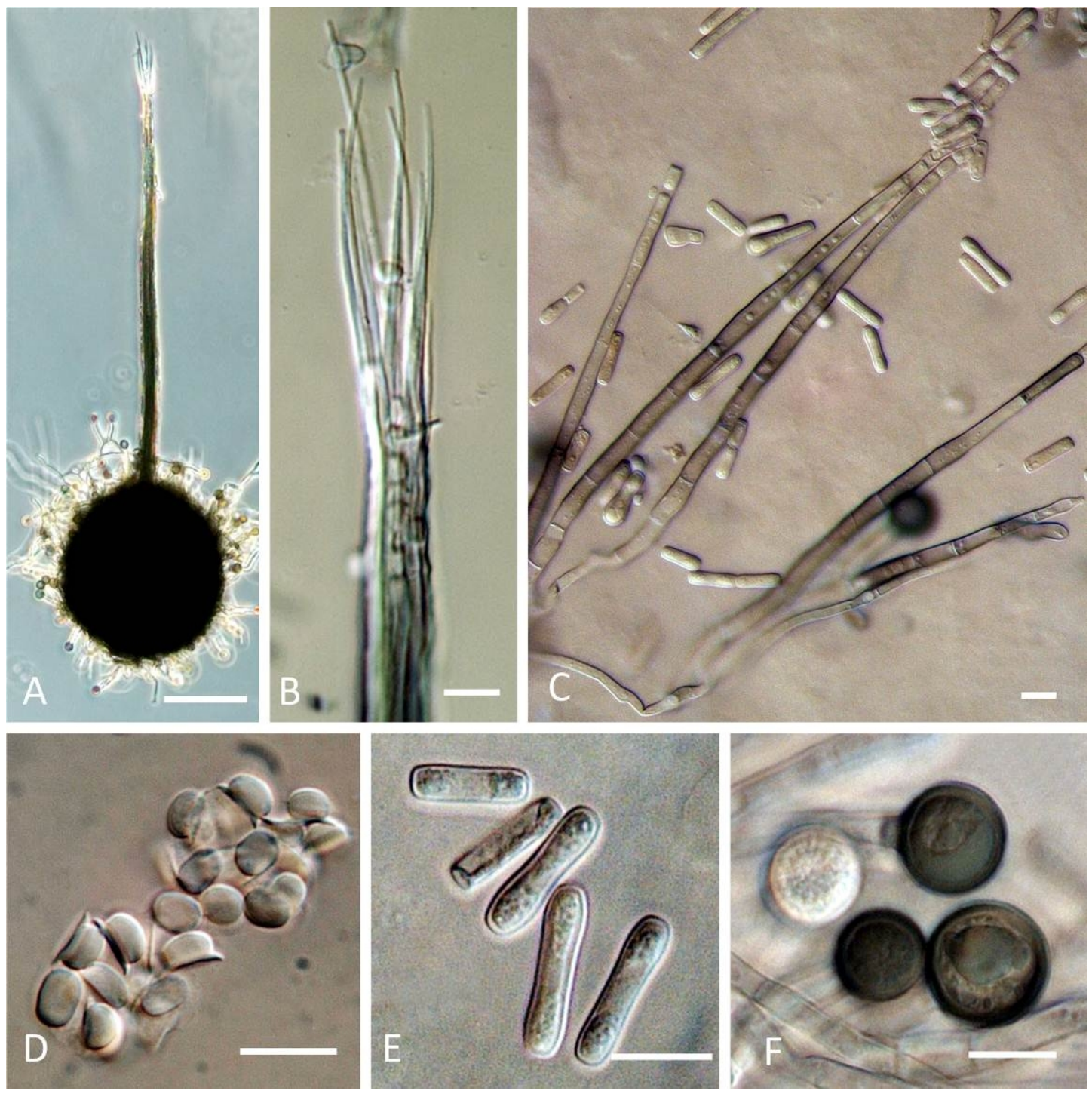

Figure 10. Morphological characteristics of Ceratocystis zambeziensis sp. nov. A, ascomata with globose base and extended neck; B, details of neck tip showing divergent ostiolar hyphae; $\mathrm{C}$, tubular phialidic conidiophores; D, cucullate (hat-shaped) ascospores; E, bacilliform primary conidia; F, spherical aleurioconidia. Scale bars, A: $100 \mu \mathrm{m}$; B, C, D, E, F, G: $10 \mu \mathrm{m}$ 